\title{
Public Participation as a Tool for Solving Socio-Spatial Conflicts of Smart Cities and Smart Villages in the Sustainable Transport System
}

\author{
Marek Ogryzek $^{1, *(\mathbb{D})}$, Wioleta Krupowicz ${ }^{2}$ (D) and Natalia Sajnóg ${ }^{3}(\mathbb{D}$ \\ 1 Department of Land Management and GIS, Institute of Spatial Management and Geography, University of \\ Warmia and Mazury, 10-719 Olsztyn, Poland \\ 2 Department of Spatial Planning and Environmental Sciences, Faculty of Geodesy and Cartography, \\ Warsaw University of Technology, 00-661 Warsaw, Poland; wioleta.krupowicz@pw.edu.pl \\ 3 Department of Cadastre and Land Management, Faculty of Geodesy and Cartography, Warsaw University of \\ Technology, 00-661 Warsaw, Poland; natalia.sajnog@pw.edu.pl \\ * Correspondence: marek.ogryzek@uwm.edu.pl
}

\section{check for} updates

Citation: Ogryzek, M.; Krupowicz, W.; Sajnóg, N. Public Participation as a Tool for Solving Socio-Spatial Conflicts of Smart Cities and Smart Villages in the Sustainable Transport System. Remote Sens. 2021, 13, 4821. https://doi.org/10.3390/rs13234821

Academic Editors: Anna Visvizi, Wadee Alhalabi, Shahira Assem Abdel Razek, Paolo Gerli and Orlando Troisi

Received: 28 October 2021

Accepted: 22 November 2021

Published: 27 November 2021

Publisher's Note: MDPI stays neutral with regard to jurisdictional claims in published maps and institutional affiliations.

Copyright: (c) 2021 by the authors. Licensee MDPI, Basel, Switzerland. This article is an open access article distributed under the terms and conditions of the Creative Commons Attribution (CC BY) license (https:// creativecommons.org/licenses/by/ $4.0 /)$.

\begin{abstract}
The article presents modern international approaches to public participation in Sustainable Transport System planning. It discusses the causes of social conflicts during the implementation of transport infrastructure projects using the example of implementation of several Polish strategic road infrastructure projects. It provides the assessment of the form, scope, and scale of stakeholders' involvement in the decision-making process. Among mitigation measures, the authors propose a model solution based on a comprehensive approach to public participation in road infrastructure planning in smart cities and smart villages within a Sustainable Transport System. The proposed idea involves a model of multi-criteria spatial analysis using the analytic hierarchy process (AHP) developed in the geographical information systems (GIS) environment, which-apart from technicalfunctional, environmental, cultural, economic, financial, and social criteria-also encompasses preferences expressed by local community representatives. The model includes eight stages of public participation in the decision-making process, involving all the rungs of a ladder of citizen participation. The presented solution departs from typical social participation methods used in road infrastructure planning processes.
\end{abstract}

Keywords: Sustainable Transport System; public participation; model; multi-criteria analyses; GIS; smart cities and smart villages

\section{Introduction}

Transport infrastructure projects are perceived as catalysts for regions' competitiveness and as contributing to permanent economic growth in cities and villages [1-3]. This is especially true for transport infrastructure, including land transport infrastructure such as railroads and roads, bridges, tunnels, roundabouts, cycleways, etc., of smart cities and smart villages within a Sustainable Transport System [4,5]. The issues of sustainable development in transport, and reduction of transport's negative impact on the climate, human health, and biological diversity, have long been of interest to scientists [6-9], particularly focusing on the application of spatial modelling tools, such as geographical information systems and decision support systems $[10,11]$. Appropriate activities are also undertaken in the scope of sustainable development, as well as energy engineering and water management.

Transportation, water supply, and energy-related assets are part of the so-called "critical infrastructures" in that they provide essential services for the economy and functioning of society [12]. All procedures related to their development should therefore constitute conscious and planned effort, corresponding with environmental sustainability visions, and be reflected in a rational spatial planning [13-16] and sustainable land management $[17,18]$. 
Transport is shown to have an important role in sustainable growth of cities and villages $[19,20]$. Developing, modernising, or reconstructing the road network in a way that reflects the vision and the needs of its users but also the need to protect the environment must be a part of such sustainable growth [21,22]. Development and modernisation of transport infrastructure, its maintenance, and operation, remain main public policy challenges for the coming years in Poland. The development policy currently implemented in Poland is based on several strategic documents and government programmes:

- Poland 2030. The third wave of modernity. Long-term National Development Strategy; - National Regional Development Strategy 2010-2020: Regions, Cities, Rural Areas;

- Transport Development Strategy up to 2020 (with a prospect until 2030).

The planned development of road infrastructure in Poland concerns national, regional, and local road infrastructure.

The transport infrastructure projects, however, are implemented in a specific environment, amongst a specific local community. This may be a source of conflicts, usually resulting from a NIMBY (not in my back yard) attitude. Such an attitude is manifested by residents of a given area objecting to a potential location of a transport infrastructure project, which they perceive as bothersome, in direct vicinity of their place of residence. At the same time, they express approval for the implementation of this type of investment project, but in a different location [21-23]. The subject of the objections is therefore not the facility itself, but its location and the related threats. The phenomenon accompanies the process of siting of various infrastructure projects, including: windfarms [23-25], waste facilities [26,27], biogas plants [28], factory farms [29], and many others. Such projects are all of local character, and usually generate costs for the local communities, whereas the benefits are generally on the collective level. In the case of civil engineering and utilities infrastructure projects, the spatial range of their effect is much larger. It results from the linear nature of such infrastructure, and therefore the impact of its routing on a large number of land properties. This particularly concerns roads [30-32]. Cartographic documents in Poland and in the other European countries do not obligatorily show the legally imposed limitations of the rights of owners to use their property [33]. In addition, the provisions of the Polish Special Act on Public Road Investment Projects allow agricultural land to be taken out of production for highway projects in spite of public opposition. Siting of infrastructure should be preceded by an open dialogue with all stakeholders (i.e., residents, owners of land properties, ecological organisations, NGOs, entrepreneurs, investors, and representatives of authorities). Such dialogue is a manifestation of a functioning mature democracy, and enables obtaining knowledge from different sources and from different perspectives. One of the most important parties of the dialogue is the local community. Residents, directly affected by the impact of infrastructure, are usually the best experts on issues concerning their place of residence. Therefore, their opinion should be binding in making project-related decisions [34].

Although formally, pursuant to the applicable statutory law, in Poland the participation of citizens in the decision-making process regarding the siting of infrastructure projects is guaranteed, it does not always work effectively in practice, particularly during the stage of planning and siting of the infrastructure. This particularly concerns strategic public purpose projects. Residents frequently feel disregarded in the process of infrastructure siting, and have the feeling of injustice [35]. This leads to protests and social conflicts. Faced with unwanted infrastructure plans, they unite to defend their common good, namely, their living space. Positive aspects include the integration of local community, development and stabilisation of social capital, promotion of local leaders, and increase in participation in public life [36].

Road transport in cities is one of the main sources of air and noise pollution; therefore, a Smart City requires alternative modes of transport and alternative transit routes in line with the concept of sustainable urban transport [37]. The Sustainable Development Goals require cities to work towards transit-oriented development, as it has a positive impact 
on reducing emissions [38]. The most complete analysis is based on spatial data and the easiest way to implement it is to use GIS tools [39].

This article includes a literature review with focus on the tools and techniques enabling participation of local communities in the planning of transport infrastructure projects. It sets the background for conflicts arising in Poland in connection with the implementation of road construction projects and shows the deficiencies of approaches used in Poland and Europe. The article then discusses the possibilities of increasing the scope of local participation in decision-making processes related to implementing road construction projects. Furthermore, it proposes a model solution representing a comprehensive approach to public participation in planning of infrastructure. The concept of the model is based on the method of e-participation and on the multi-criteria analysis using geographical information systems. The proposed solution is a shift from the typical project solutions implemented in Poland, as it enables a multi-directional exchange of information between the stakeholders (the residents and the local authorities/investor), as well as identification and minimisation of socio-spatial conflicts as a result of a genuine participation of a local community in decision-making. The proposed solution is a combination of good practices from Poland and Europe. Due to the unique nature of each transport infrastructure project, and of the local context and needs, the model is characterised by flexibility, which allows it to be used in various legal, social, and spatial settings.

\section{Materials and Methods}

According to case study theory [40], detailed evidence is to be provided by longer case studies whereas the purpose of short case studies is to illustrate the underlying explanatory logic. Therefore, we have described in detail a case of the S16 road project, lasting 10 years, and several shorter ones. A modern smart city is defined in a multifaceted way based on its basic components ranging from technical infrastructure to social capital systems, hence the need for smart cities to use online platforms for communication and collaboration with citizens [41]. Within the European Union, in accordance with the INSPIRE directive, local GIS (geoportals) with the function of communication with citizens are used to accelerate the process of data modeling with social participation [42]. This approach blends with the strategic principles of multidimensional components of a smart city relating to the three main dimensions: technology, people, and institutions [43].

The concept of the model is based on the principles of the citizen e-participation method [44] and the multi-criteria analysis using geographic information systems. In this case, the use of e-participation encourages engagement from a greater number of citizens than conventional forms of consultation, which stems from the lack of temporal and spatial constraints that these solutions entail. Citing Poorazizi, Steiniger, and Hunter [45], the development of participatory technologies based on GIS systems facilitates the creation of new generation of bottom-up public participatory GIS (PPGIS) platforms that contain content generated by users in a spatial data infrastructure.

The key element of the model is developing a hierarchy of goals at the beginning. This is especially important for group decision making, as it ensures a structured debate and facilitates arriving at consensus (or forging a compromise). A hierarchy of goals is a key element of many multi-criteria analyses, including the analytic hierarchy process (AHP) (whose stages and mathematical foundations were presented in numerous publications by Thomas L. Saaty) [46-48], often applied in geographical information systems [49].

The AHP method is based on the assumption that the majority of complex decisionmaking problems can be broken down and presented in the form of a hierarchical tree (hierarchical structure). The structure of the AHP model includes several levels. The highest level represents the primary goal of the decision-making process. The implementation of the goal is determined by the criteria located on the lower levels. These, in turn, depend on the corresponding sub-criteria (factors). The bottom level represents decision alternatives that are ordered from the most to the least preferred to facilitate making of the decision on selecting one of them. This relatively simple hierarchy can be expanded. Intermediary 
stages can be introduced, such as auxiliary (subordinate) goals, or groups of decisionmakers with different preferences-in this manner the obtained result will also depend on the value of judgements involved in the decision-making process. This helps avoiding difficulties noted by Benjamin Franklin in his famous letter addressed in 1772 to the wellknown English chemist philosopher Joseph Priestley: "when these difficult cases occur, they are difficult chiefly because while we have them under consideration all the reasons pro and con are not present to the mind at the same time" [50].

The AHP method applied together with GIS software has an evident spatial aspect, manifested both in the defined goal (related to spatial planning) and in the set of criteria (referring to various aspects of space) and spatial data for implementation of the criteria. It covers steps related to determining usefulness of a plot of land for a particular purpose, including the designation of the best location [51] and tasks involving comparison of specific alternatives for the purpose of selecting the best, e.g., the best route for a road development [52].

A literature review [52-59] shows a significant role of multi-criteria spatial analyses in decision-making processes in a variety of fields. Multi-criteria analyses supporting decision making are methods of structuring a decision problem [53]. They can be used to identify and minimise potential spatial conflicts at an early stage of planning [60]. In most general terms, spatial analyses that consider a set of criteria in decision making may be understood as a process of combining and processing geographic input data corresponding to the criteria to create a decisions map [61-64]. These analyses enable not only the values of individual criteria to be considered but also the decision-makers' preferences towards individual sets of criteria. Thus, the result is dependent not only on the spatial distribution of values of criteria under consideration but also on the value of judgements included in the decision-making process [65-67]. This is why multi-criteria analyses find a wide application in defining optimal locations for infrastructure investment projects where the social and environmental factors, with their characteristically large number of interrelationships and interactions, have a key impact on the decision-making process $[34,68,69]$.

The design works schedule is presented in Figure 1, broken down into stages. The design works schedule for a road construction project divided into investment process work and information activities with detailed description is presented in Table 1.

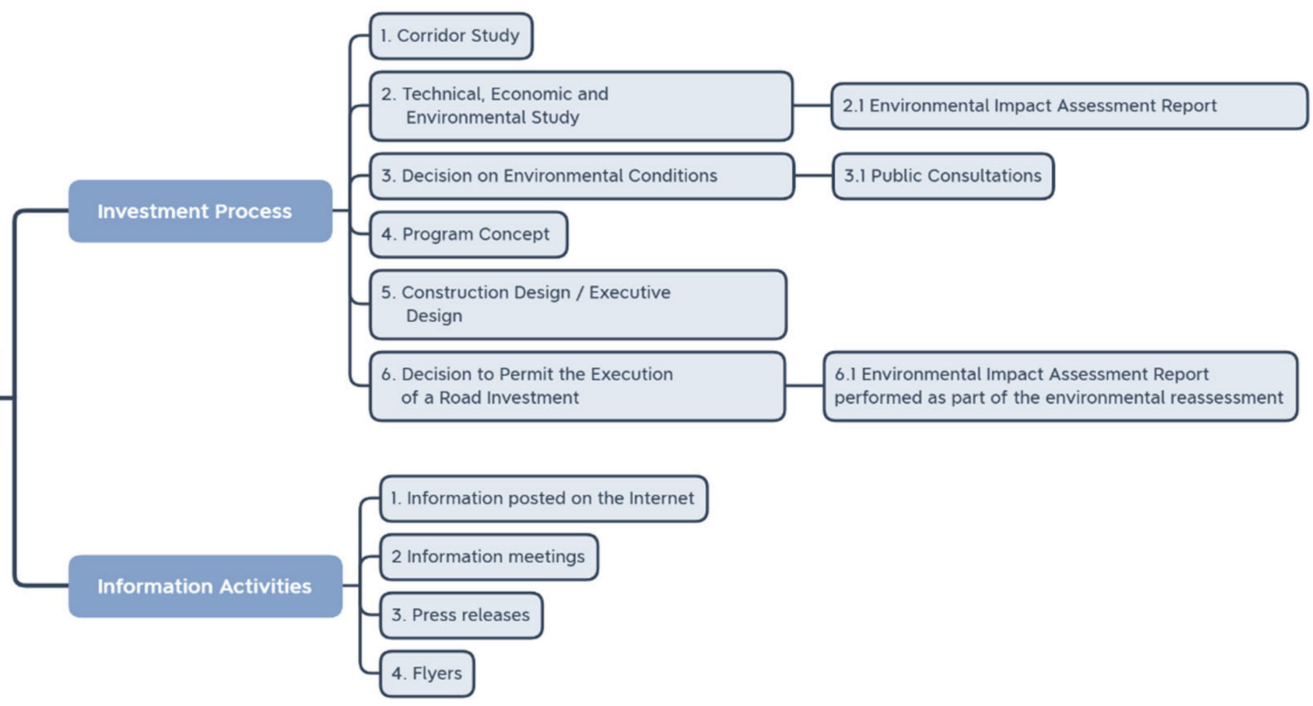

Figure 1. Road construction design works schedule. 
Table 1. Detailed road construction design works schedule.

\begin{tabular}{|c|c|c|}
\hline Ref. No. & Investment Preparation Stage & Stage Description \\
\hline 1. & Corridor Study & $\begin{array}{c}\text { - is not mandatory } \\
\text { - determines the location of the roadway (corridor) taking into account the regional and } \\
\text { local geographic, natural, and social conditions, } \\
\text { - serves as a preliminary assessment of investment profitability for the Investor } \\
\text { - determines route alternatives on maps at a scale of } 1: 25,000, \\
\text { - eliminates the technically unrealistic, unsafe, economically questionable solutions or } \\
\text { solutions which are the least favourable from the natural and social point of view, } \\
\text { - is prepared taking into the account the opinion of local authorities, but without } \\
\text { participation of the public. }\end{array}$ \\
\hline
\end{tabular}

- is obligatory when the type of investment requires several different route alternatives, - is the analysis of potential route alternatives on maps at a scale of 1:5000 aimed at finding the optimal route,

- determines the material and financial scope of the project and its efficiency, - presents in detail the routing of individual alternatives (on the basis of the analysis of

Technical, Economic, and Environmental Study
Environmental Impact Assessment Report

alternative routes and the opinions received) and determines the types and basic technical parameters of facilities to be constructed, - provides information for preliminary investor's decision,

- determines the potential timeline for the execution of the investment, - facilitates obtaining the decision on environmental conditions,

- opinions and conclusions on the design solutions are collected and a report is prepared

with opinions of the public, possibilities and difficulties of their implementation, - local governments provide written opinions on the route alternatives.

- is prepared obligatorily as the basis for the application for the decision on environmental conditions,

- the body appointed to issue the decision examines whether the route indicated by the investor as the scenario to be executed has been properly assessed and whether it will not cause negative environmental impact at the stage of execution, exploitation, and decommissioning,

- should include assessment of at least one alternative option (the so-called optimal alternative option),

$\begin{gathered}\text { Decision on environmental } \\ \text { conditions (the environmental } \\ \text { decision) }\end{gathered}$

- for investments in motorways and expressways, an annual wildlife stocktaking exercise is obligatory.

- is issued before submitting the application for the building permit,

- specifies the conditions that the investor should meet in order to be allowed to implement the investment according to the investor's recommended scenario,

- defines the boundaries of the area on which the investment may be located,

- if the investment, in the scenario indicated by the investor, will have a negative impact on the environment, the authority refuses to issue the environmental decision.

3.1 Public Consultation

- ensures public participation in administrative proceedings regarding the issuance of the environmental decision, - is mandatory.

- is not obligatory,

- the scope of this study is a technical design, including, inter alia, the design of the road system, made on a map at a scale of at least 1:1000,

- is performed after obtaining the environmental decision for the scenario to be implemented,

- this study is a part of the description of the subject of the contract for construction works,

4. $\quad$ Program Concept

- specifies technical solutions for the road scenario to be implemented supported by geological research,

- during the development of the Program Concept, information meetings are also organized, however, it is not required by law to gather the opinions of residents on the proposed technical solutions, such as the access and transport connection services to and from the construction site,

from the construction site,
- the documentation is corrected according to the public's comments, however, the technical solutions cannot go beyond the limits indicated in the environmental decision.

- Construction Design is a study required as an attachment to the application for a building permit or a permit for implementation of a road investment, 5. Construction Design/Executive
Design

- Executive Design is a study including technological details of the Construction Design, enabling construction of a road section,

- In the course of developing the Executive Design, it is possible to hold meetings with residents in order to discuss proposed solutions to technical or engineering problems.

6ecision on a permit for
$\begin{gathered}\text { Dementation of a road } \\ \text { investment }\end{gathered}$
$\begin{gathered}\text { Environmental Impact } \\ \text { Assessment Report for the } \\ \text { project carried out as part of the } \\ \text { environmental impact } \\ \text { reassessment }\end{gathered} \quad \begin{gathered}\text { - the reassessment Report evaluates the compliance of the design solutions included in the } \\ \text { Construction Design with the conditions imposed by the environmental decision, }\end{gathered}$
- the reassesment Report is subject to public review,


Table 1. Cont.

\begin{tabular}{|c|c|c|c|}
\hline & Ref. No. & Investment Preparation Stage & Stage Description \\
\hline \multirow{4}{*}{ 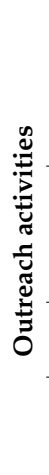 } & 1 & $\begin{array}{l}\text { Information posted on } \\
\text { the internet }\end{array}$ & $\begin{array}{c}\text { https: / / www.gddkia.gov.pl/ (access } 20 \text { May 2021) } \\
\text { https: / /www.gddkia.gov.pl/pl/1077/mapa-stanu-budowy-drog (access } 20 \text { May 2021) } \\
\text { https:/ / twitter.com/gddkia (access } 20 \text { May 2021) } \\
\text { https://www.facebook.com/gddkia (access } 20 \text { May 2021) } \\
\text { - websites dedicated to individual investments }\end{array}$ \\
\hline & 2 & Information meetings & $\begin{array}{l}\text { Information meetings are aimed at informing the public about the investment project at the } \\
\text { stage at which legitimate requests for design changes can still be introduced into the } \\
\text { documentation. At the meetings and after the meetings, applications requests for } \\
\text { correction of design solutions are collected. }\end{array}$ \\
\hline & 3 & Press releases & $\begin{array}{l}\text { Published in the local press, in particular before information meetings, in order to inform } \\
\text { about the investment project and about the date of information meetings. }\end{array}$ \\
\hline & 4 & Flyers & $\begin{array}{c}\text { Flyers with brief information about the investment project distributed at information } \\
\text { meetings, sent to municipalities, displayed at the Branch Office, distributed at other } \\
\text { investment projects-related meetings. }\end{array}$ \\
\hline
\end{tabular}

Source: Own elaboration based on data from the General Directorate for National Roads and Motorways in Olsztyn.

\section{Public Participation in Planning of Road Infrastructure Projects}

\subsection{Literature Analysis}

Managing investment projects in a manner that accommodates the participatory approach can help achieve a number of measurable benefits in the form of: (1) improved quality of decisions, (2) reduced costs and delays in the implementation of work, and (3) increased credibility and legitimacy of public authorities [70]. The degree of social involvement in spatial planning is most often illustrated by Arnstein's metaphor of a 'ladder of citizen participation' [71]. Arnstein distinguishes eight levels of public participation. The first two, i.e., (1) manipulation and (2) therapy are collec tively referred to as 'nonparticipation'. Their goal is not to enable people to participate in participatory processes, but to enable power holders to educate the participants. The next three levels, i.e., (3) informing, (4) consultation, and (5) placation constitute a form of 'tokenism' that allows have-nots to hear and have a voice and to give advice, but without the right to decide. Higher on the ladder are the levels of civic empowerment with the increasing decisionmaking power. Level 6 is partnership (6) that enables the public to negotiate and encourages dialogue with the authorities. The highest rungs of the ladder include: (7) delegated power and (8) citizen control, corresponding to a situation where minorities retain a majority vote in decision-making or have full decision-making power. The highest rungs of the ladder, therefore, correspond to cooperation and co-decision. Cooperation ensures that the inhabitants participate in the discussion as one of the parties, i.e., it gives them the possibility to convince other participants of the preferred solutions. The local community is actively involved in the decision-making process, which creates neighbourly ties and makes the whole process more sustainable and effective. The highest level of civic participation, however, is shared decision making, as it entails full partnership between the authorities and the inhabitants, which consists in delegating to the society certain competences (but also responsibilities) concerning the actions and decisions taken. Thus, citizens have a real impact on the planned activities that (directly or indirectly) concern them.

The extent to which the processes of public participation in spatial planning and technical infrastructure projects are subject to regulation varies from country to country [72]. In addition to participation defined by statute, non-statutory participatory techniques are also recommended in spatial planning as long as they are not contrary to the law. Departure from the statutory minimum and transitioning to a model of action based on a genuine dialogue and participation seem to be the right direction for change in the manner that important investment projects are conducted, the direction that enables growth of social capital. If participants experience real interaction and exchange of experiences, and their time and energy prove to be truly useful, the level of their engagement increases. This trend, covering a very large number of countries on different continents, including Western Europe, parts of South and North America, as well as Australia and New Zealand [66], has been initiated or strengthened by international communities such as the 
European Union [73]. When it comes to newly designed technical infrastructure investments, the choice of participatory techniques is very important. This choice should offer the possibility of confronting different views, getting to know the local context, and identifying potential conflicts.

Techniques used in public participation can be divided into three main groups [74]: (1) studies, (2) debates, (3) workshops, with an additional group of mixed techniques that combine the techniques presented in the three main groups noted in Table 2.

Table 2. Summary of techniques used in participatory activities.

\begin{tabular}{|c|c|}
\hline \multicolumn{2}{|c|}{ Summary of Techniques Used in Participatory Activities } \\
\hline Studies & $\begin{array}{l}\text { Quantitative methods: } \\
\text { - questionnaire survey } \\
\text { - geo-questionnaire } \\
\text { Qualitative methods: } \\
\text { - qualitative interview } \\
\text { - research walk } \\
\text { - urban prototyping }\end{array}$ \\
\hline Debates & $\begin{array}{l}\text { - open meeting } \\
\text { - literary café }\end{array}$ \\
\hline Workshops & $\begin{array}{c}\text { - Future City Game } \\
\text { - Planning for Real } \\
\text { - participatory planning }\end{array}$ \\
\hline Mixed techniques & $\begin{array}{c}\text { - } \text { citizens' panel }^{\text {- deliberative poll }}{ }^{\circledR} \\
\text { - action research (participatory assessment) } \\
\text { - sentimental map } \\
\text { - World Café } \\
\text { - citizens jury } \\
\text { - discussion game } \\
\text { - } \text { Charette }^{\mathrm{TM}}\end{array}$ \\
\hline
\end{tabular}

Source: Study [74].

Each of the proposed techniques has different applications and allows for the achievement of different goals, such as: diagnosis of needs, exchange of knowledge and experience, problem-solving, decision making, creating action plans, creating innovative solutions, project appraisal, conflict resolution, and education. Comprehensive participation usually requires the use of several techniques.

The appropriate choice of techniques depends on, among other things: intended goal, stage of the procedure, target group of participants, time of implementation, available resources, requirements for implementation, and level of difficulty of implementation.

Mixed techniques are often used in integrated rural development projects, in particular by a working group meeting on a regular basis that elaborates recommendations and specific solutions for a given subject matter. The Bavarian Schools for Rural and Agricultural Development, established in Bavaria in order to support educational activities in the field of rural development [75], have extensive experience in this field. These schools offer one-day or multi-day seminars. The seminars are often town- or project-specific, as agreed with the stakeholder group, and are conducted for working groups dealing with various topics related to rural development (e.g., nature and landscape conservation, cultural heritage, and village renewal) [76].

The members of the group are selected from among rural residents and experts working for the company preparing the area development plan who are invited to the group. The group usually works on the results of a prior problem diagnosis exercise. The model manner of implementation of this technique involves setting the goal for the work of individual teams, as well as their regular assessment. The final shape of the solutions proposed by the group is verified by the local authorities. The working 
group is monitored at the stage of work on a specific concept of spatial development [65]. In many cases, modern technologies support the process of public participation. Hansen and Prosperi [77] described how the simple idea of a ladder of citizen participation is being developed into more advanced structures that account for the level of power in the decision-making process [78], the level of access to information, and the level of interaction (e-participation), among other factors. E-participation in spatial planning builds on the opportunities offered by the Internet and geographical information systems. Examples of the use of e-participation can be found in Hanzl [79,80], among other studies. Using the opportunities provided by modern information technology can make it easier to 'climb up' the ladder of citizen participation. The use of geospatial technologies for public sharing on planned land development results from the obligation to include this type of information in the country's spatial information infrastructure, in accordance with the provisions of the INSPIRE Directive [81].

The authorities responsible for implementing legal regulations are required by statute to consider the opinions of stakeholders [82]. Poland is bound by the provisions of the Aarhus Convention (the Convention on Access to Information, Public Participation in Decision-making and Access to Justice in Environmental Matters) as it ratified the Convention in 2001, upon the approval of the Polish Parliament, and because of its membership in the European Union. The Polish legal system is based on a hierarchy of the sources of law with the primacy of the Constitution of the Republic of Poland [83], followed by international agreements ratified with consent of the Parliament granted by way of statute, and then the national statutory law, such as the following national statutory acts:

(1) the Act of 14 June 1960 The Code of Administrative Procedure [44],

(2) the Act of 3 October 2008 on Providing Information on the Environment and Environmental Protection, Public Participation in Environmental Protection and on Environmental Impact Assessment [84],

(3) the Act of 27 March 2003 on Spatial Planning and Management [85] should always be interpreted in accordance with the Aarhus Convention and in the case of any discrepancy between the statutory provisions and the Convention, the Convention provisions shall prevail.

The statutory law provides for a decision on environmental conditions (decyzja o środowiskowych uwarunkowaniach, DŚU), the so-called environmental decision, to be issued for road and utilities infrastructure projects. The decision has impact on the routing of such projects [85]. The public concerned may influence the provisions of the environmental decision by taking part in the decision-making process, submitting opinions and comments on the planned project, and using their right of appeal. Obtaining the environmental decision is the first stage in the procedure for applying for administrative decisions such as the decision on the location of a public purpose investment project (decyzja o ustaleniu lokalizacji inwestycji celu publicznego, decyzja ULICP) or a decision granting the building permit (decyzja o pozwoleniu na budowę, DPB). The obligatory component of a procedure for a strategic environmental assessment (SEA), as well as an environmental impact assessment (EIA), is public participation. It is required for each investment plan to be included in the land-use planning documents [85]. This entails the adoption of a local land development plan (miejscowy plan zagospodarowania przestrzennego, MPZP) or (if no plan is adopted or if it is not required to draw up such plan) issuing a land development decision (decyzja o warunkach zabudowy, WZ) or, if applicable, a decision on the location of a public purpose investment project. Public participation in the spatial planning process in Poland is guaranteed by statute $[44,84,85]$. At the stage of the work on planning documents and, additionally, in the case of investments with significant impact on the environment, at the stage of the environmental decision procedure, the stakeholders may influence the procedure in a formal manner by submitting comments, requests, appeals, and complaints against non-final decisions or in an informal manner by exerting influence on the authority issuing the decision or on the investor. The decision-making flow chart 
showing key stages that enable blocking of a transport infrastructure project as a result of active participation of the local community is presented in Figure 2.

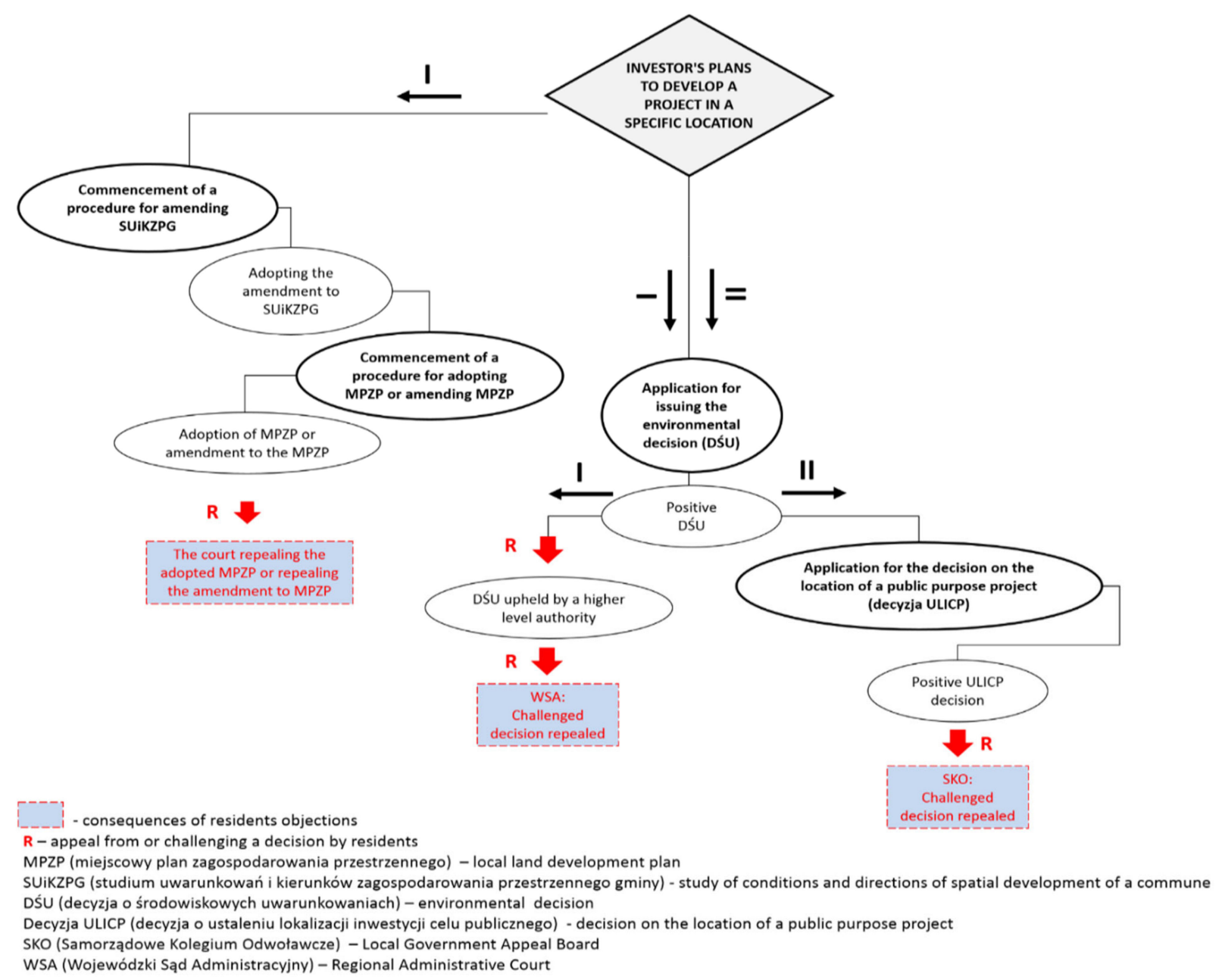

Figure 2. The influence of the local community on the decision-making process in Poland depending on the necessity of (I) adopting (or amending) the local land development plan and/or (II) issuing the environmental decision. Source: Own elaboration based on [86].

Accession of Poland to the European Union in 2004 and the resulting inflow of EU funds was a significant factor of intensification of investment processes throughout Poland. It began the necessary modernisation and development of infrastructure with a view to adapting it to EU standards. The transport infrastructure projects, however, have frequently met with opposition from local communities displaying NIMBY attitudes. The objections were directed not so much against the planned facility itself as against its location and the threats involved [87]. Opposing attitudes of local communities towards the planned projects could be a manifestation of: (1) the residents' suspicions concerning the investor's motivations [88], (2) their feeling of exclusion from the decision-making process or of the "window-dressing" nature of public consultations [89], or (3) the deficit of trust in authorities and experts [90].

Currently, NIMBY-type conflicts in Poland are an important problem of the local social and political life and a reflection of a deficient system of spatial planning and management. The literature on this subject presents this phenomenon in various contexts: (1) the context of infrastructure siting protests [91], (2) the environmental context [85], (3) the ecological context [92], (4) the spatial management context [93], and (5) the socio-spatial context [35]. The most frequent source of conflicts are technical infrastructure investment projects 
related to energy production and supply, as well as transport projects, in the case of which the NIMBY syndrome can have a huge impact on the decision-making process [86]. The parties to the conflict include the residents, opposing the unwanted developments; the investors, having to deal with the protesting residents; and the authorities. The factors that contribute to the rise of the NIMBY phenomenon manifesting itself in the opposition of local communities against transport infrastructure projects in Poland include:

1. Lack of adopted local land development plans:

In the light of the provisions of the Act of 27 March 2003 on Spatial Planning and Management [85] the land-use planning policies in Poland are implemented mainly at the level of communes. The basic instrument for shaping the local policies is a study of conditions and directions of land development of a commune (studium uwarunkowań $i$ kierunków zagospodarowania przestrzennego gminy, SUiKZPG). Specific tasks foreseen by the policies are implemented, however, through a local land development plan (miejscowy plan zagospodarowania przestrzennego, MPZP) and, in the absence of such plan, they are implemented by way of a decision on the location of a public purpose investment project (decyzja o ustaleniu lokalizacji inwestycji celu publicznego, decyzja ULICP) or a land development decision (decyzja o warunkach zabudowy, WZ). Only the local land development plan is the instrument that actually implements the spatial planning policy of the commune. The plan is an instrument of local law defining the purpose and the conditions of land development, in accordance with the premises of the study of conditions and directions of land development of the commune (SUiKZPG), and the provisions of any policies adopted above the local level. The study itself does not constitute a statutory act, therefore it is not binding for the commune authorities that may depart from its conditions when issuing their land development decisions. This constitutes a major weakness of the Polish spatial planning system. Because it is permitted to carry out construction projects on areas not covered by land development plans (MPZP), a growing number of spatial conflicts of a varied nature and range can be observed [94]. The coverage of Poland with the local land development plans is insufficient and the pace of their adoption is too slow. By the end of 2017, the coverage was approximately 30.5\% [95]. The local land development plans tend to be fragmented and adopted only for the purpose of implementing specific projects. The lack of land available for transport infrastructure projects, resulting from elimination of land reserves that used to be made for important transport infrastructure, is another significant problem. The origin of this problem dates back to 2003 when the law was changed, repealing all local land development plans adopted before 1 January 1995.

2. Possibility of expropriation of agricultural land for investment purposes:

Due to its linear nature, transport infrastructure projects often give rise to socio-spatial conflicts concerning mostly agricultural land. This results from the structure of land use in Poland. At the end of 2017, agricultural area comprised $60.16 \%$ of the total area of Poland, including $43.76 \%$ of arable land [86]. It must also be noted that the structure of Polish agricultural holdings is very fragmented $[34,96,97]$. In addition, continuous sprawl of suburban residential developments onto agricultural land makes it difficult to implement public purpose investments (such as construction of city bypasses and other roads, as well as power lines). Planning the location of such developments on areas that have not been reserved for this purpose in the local spatial development plans gives rise to protests and social conflicts and results in costly expropriation and compensation procedures. More and more conflicts emerge as the number of inhabitants and the land-use intensity in such areas continues to increase [98].

3. Intensive development of technical infrastructure caused by the dynamic economic growth of Poland:

The continuous social, economic, and technological growth of Poland has entailed the necessity to provide the inhabitants with services to satisfy their basic need for utilities infrastructure, such as transmission and distribution lines, and for transport infrastructure [99]. In addition, investors wish to construct facilities using modern technologies that 
are new to local communities, evoking their (justified or unjustified) concern and giving rise to protests.

4. Increase in civic awareness:

Since the beginning of the systemic transformation in Poland (1990), citizens have become increasingly aware of their civic rights, also with regard to implementation of investment projects. The key legal act in this respect was the Act on Providing Information on the Environment and Environmental Protection, Public Participation in Environmental Protection and on Environmental Impact Assessment of 3 October 2008 [84].

5. Attachment to the place of residence:

The attachment to a place is an emotional, positive connection between an individual and the environment in which they live [100,101]. It is therefore a specific bond between a person and not only the place, but also the surroundings and the neighbourhood. The place can be considered from three different aspects [102]: (1) as a location expressed by coordinates, (2) a shape (locale), i.e., type of buildings, existing infrastructure, and nature, and (3) its meaning (sense of place) understood as a cultural ecosystem service and multidimensional concept involving emotional attachment, satisfaction, and identity [103-105]. Therefore, place attachment can be considered in two dimensions [106]: (1) place identity and (2) place dependence. Place dependence refers to functional features of a place that facilitate certain activities and emotional connections [107]. Place identity denotes how physical and symbolic features of places are embodied in an individual's sense of identity [101]. Any actions aimed at disrupting the place, including relocation, physical landscape change, or changes in spatial development, result in negative social emotions. Individuals subjected to such processes may deploy coping mechanisms (e.g., resisting change, re-establishing place meanings, questioning powerful interests) to reduce threats of disruptions and protect their sense of attachment [108].

\subsection{Case Studies}

Routing of the S16 road in a section of Mragowo-Orzysz-Ełk:

In the case of very complex projects, such as linear investments for high class roads like motorways and expressways, it is extremely difficult to introduce any design changes at the stage of the administrative proceedings aimed at issuing the decision on environmental conditions (the environmental decision). All the necessary analyses carried out prior to the submission of the application for the issuance of the environmental decision, such as, for example, the annual environmental stock-taking exercise, require the previous stages of the procedure to be repeated in case of any significant design changes. Therefore, the Branch of the General Directorate for Roads and Motorways (GDDKIA) in Olsztyn decided to organize the required information meetings at the early stage of the project. The goal was to inform the public about the investment project, route alternatives, and design solutions and to collect opinions of the public on the initially adopted design solutions, as well as to implement any well-founded comments to the design solutions at the early stage of the design work. Public participation has its foundation in statutory law [86] and is ensured by the Regional Directorate for Environmental Protection (RDOŚ) at the stage of the administrative proceedings for the issue of the environmental decision or by the Governor as part of the environmental impact assessment.

In the case of the construction of the Mragowo-Orzysz-Ełk S16 section, the first design work was performed already in 2007, based on the GDDKiA Order No. 30 of 8 November 2005 under the title "Stages and Composition of Design Documentation for Roads and Bridges in the Task Preparation Phase". In 2007 and 2008, an external design company selected in a tender (Pracownia Projektowo - Konsultingowa Dróg i Mostów) prepared 16 alternatives of the possible routing of the S16road. In 2008, meetings were held in 17 villages located in the vicinity of the proposed alternative DK16 routes, attended by a total of 316 residents, and an "open day" was organized at the Town Hall in Orzysz, attended by 30 residents. In 2009, meetings were held in 16 towns along the route planned, 
attended by a total of 342 residents. In addition, a website was set up for the project: www.mragowo-orzysz.pl, accessed on 22 November 2021 (it is no longer active). The local press published notifications of the information meetings, and of the possibility to submit opinions during the meetings via the website and by e-mail or in writing to the GDDKiA branch in Olsztyn, as well as to the road design company. Information leaflets were printed and distributed to the residents. Comments and opinions could be submitted also on an internet forum, at www.mragowo-orzysz.pl, accessed on 22 November 2021 and www.orzysz-elk.pl, accessed on 22 November 2021. The validity of the public comments was verified by both the GDDKiA staff and the design company. As a result of numerous protests lodged during information meetings, the General Directorate for National Roads and Motorways (GDDKiA) decided to analyse additional alternatives, the so-called "social" alternatives. The General Directorate for National Roads and Motorways, on the basis of the applications submitted to its Olsztyn Branch with the "social" alternative routes, announced a tender for the preparation of the Technical-Economic-Environmental Study (STEŚ) for the new alternatives. As part of the tender, a design company was selected that, on the basis of social suggestions, laid down the alternative routes as proposed by the public (provided the appropriate parameters), and then prepared the STEŚ Study for these alternatives.

Figures 3 and 4 shows alternatives A (in blue), B (in black), and C (in red) of the S16 road route.

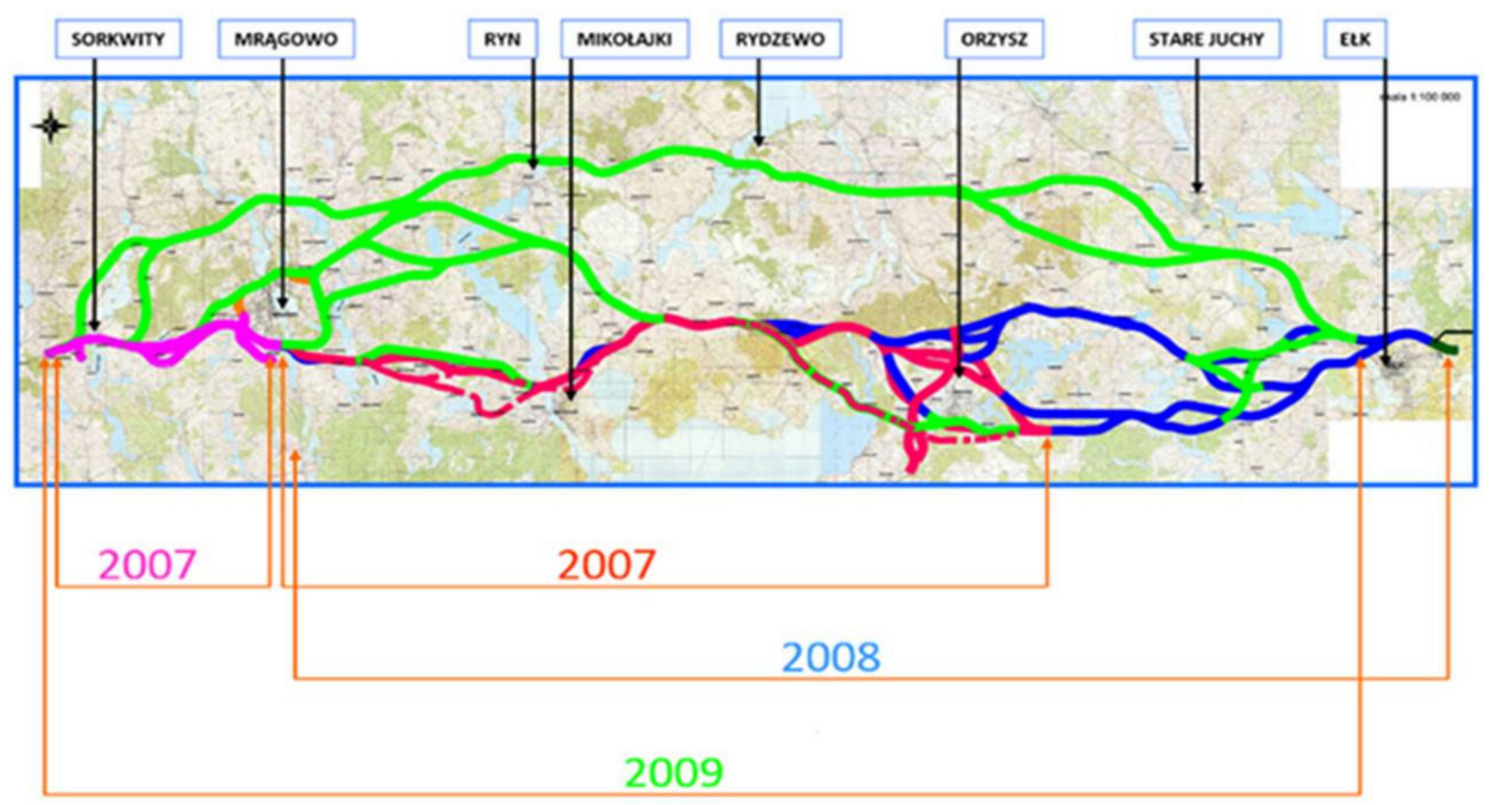

Figure 3. Route alternatives for the S16 road developed in 2007-2009. Source GDKKiA.

In 2007-2009, the Technical, Economic and Environmental Study Phase I (STEŚ I) was carried out, in accordance with the GDDKiA Order of 2005. This study corresponds in its scope to the Corridor Study (SC). Following this study, the Department of the Environment of the GDDKiA recommended seven alternatives of the S16 routing for further analysis. In 2010-2012, the Technical-Economic-Environmental Study-II (STEŚ-II) was carried out in accordance with the Order of 2005, which according to the Order of 2015 corresponds to the Technical-Economic-Environmental Study (STEŚ) for seven alternatives, i.e., I, Ia (now C,) II, IIa, III, IV (now A), Iva, and the Environmental Impact Assessment (EIA) Report. In accordance with the internal procedure of the GDDKiA, the summary of the EIA stage of the proceedings should take place at the meeting of the Investment Projects Assessment Team (ZOPI) by a GDDKiA Branch Director. Apart from the employees of the relevant GDDKiA departments, the representatives of the local authorities and other stakeholders (e.g., the police, the Road Transport Inspection, the Office for Spatial Planning 
of the Warmińsko-Mazurskie Voivodeship) were also invited to the meeting. The Projects Assessment Team (ZOPI) meeting took place on 11 April 2012. At the meeting, the ZOPI Team recommended the preferred route alternative to be implemented. After the ZOPI meeting, the Commission for the Evaluation of Investment Projects (KOPI) of the GDDKIA convened (as well as the representatives of the relevant GDDKIA Departments and of the Ministry of Infrastructure, local authorities were also invited to the meeting). KOPI ultimately recommended a route alternative that was then proposed by the GDDKIA in the application for the environmental decision as the alternative to be implemented. The meeting of KOPI took place on 17 September 2013. In the case of the investment in question, KOPI recommended route alternative IV (i.e., the current route alternative A). However, due to the fact that the route alternative IV had a significantly negative impact on the Natura 2000 area, the design solutions for the section that passes through the Mazurska Ostoja Żółwia Baranowo Natura 2000 area had to be adjusted so as to exclude significant negative impact of the investment on the Natura 2000 area. In 2013, due to lack of funding, design work for the investment in question were suspended. In 2017, work resumed for the three most advantageous route alternatives, which were given new names:

(a) Alternative A-former alternative IV, the alternative recommended by ZOPI and KOPI.

(b) Alternative B-former alternative V developed in 2015 (in accordance with the findings of KOPI), which aims to bypass the most valuable areas of the Mazurska Ostoja Żółwia Baranowo Natura 2000 Area.

(c) Alternative C - previously alternative Ia, the most advantageous alternative as it does not collide with Mazurska Ostoja Żółwia Baranowo Natura 2000 area.

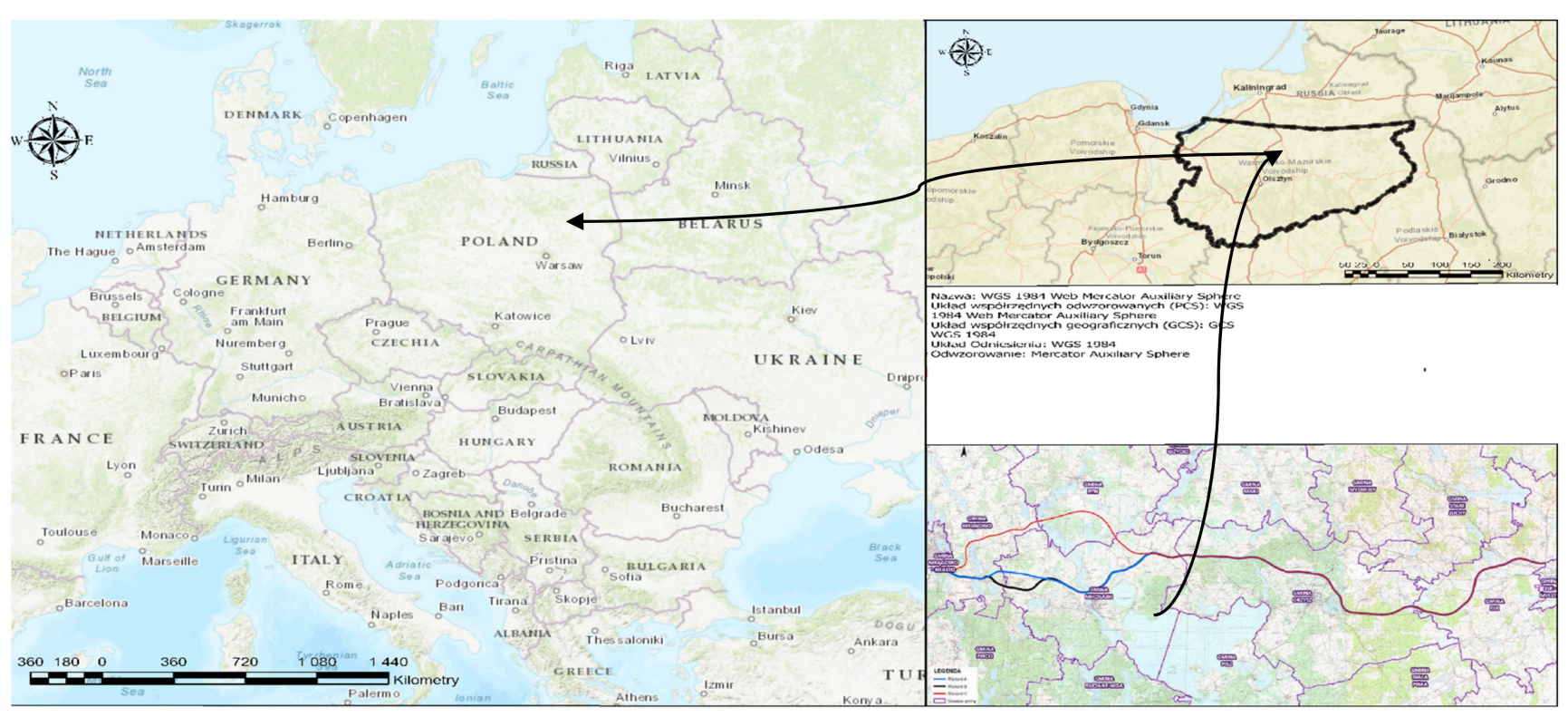

Figure 4. Route alternatives for the DK16 road. Source: Own elaboration based on data from the General Directorate for National Roads and Motorways in Olsztyn.

At the beginning of April 2020, informational meetings were organized in Mragowo, Mikołajki, Orzysz, Ełk, and Ryn. In addition, information leaflets were published, the website http://s16.com.pl/, accessed on 22 November 2021 was launched, and links to the visualization of the road route alternatives were provided. Together with the University of Warmia and Mazury, a debate on the planned construction of the S16 expressway was organized. It was attended by representatives of local government, NGOs, and scientists. The participants of the debate could put forward arguments both for and against the construction of the road. The debate was originally scheduled to take place in April 2020 in 
Olsztyn, with the participation of approximately 500 people, but due to the coronavirus pandemic and the restrictions resulting from it, the debate was conducted online. The live broadcast was watched by nearly 300 people, and approximately 400 comments were entered in the chat window. After the preparation of the STEŚ-R Stage I with the materials for the DWA, the Mazurian Road Debate was held on 17 June 2020. On 3 August 2020, the ZOPI meeting was held, which recommended the implementation of alternative B. On 9 September 2020, a meeting of the Committee of the Regions (KOPI) was held, which also recommended alternative B. On 22 December 2020, an application was filed for the issue of the decision on the environmental conditions. Currently, the administrative procedure for issuing the above-noted decision is in progress. Based on the Road Construction Design Works Schedule in Table 1 and Figure 1, a time analysis of the design works was performed to show the duration in months of the subsequent stages of the works. The results are shown in Table 3.

Table 3. Timetable in months and a schedule of road S16 construction stages.

\begin{tabular}{|c|c|c|c|}
\hline & Ref. No. & Investment Preparation Stage & Duration in Months \\
\hline \multirow{9}{*}{ 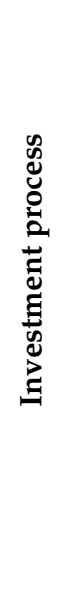 } & 1. & Corridor Study & $1-21$ \\
\hline & 2. & Technical, Economic, and Environmental Study & $22-41$ \\
\hline & 2.1 & Environmental Impact Assessment Report & $22-39$ \\
\hline & 3. & Decision on environmental conditions & $42-47$ \\
\hline & 3.1 & Public Consultation & $43-45$ \\
\hline & 4. & Program Concept & $48-67$ \\
\hline & 5. & Construction Design / Executive Design & $68-81$ \\
\hline & 6 & $\begin{array}{c}\text { Decision on permission to implement a road } \\
\text { investment }\end{array}$ & $82-88$ \\
\hline & 6.1. & $\begin{array}{l}\text { Environmental Impact Assessment Report for the } \\
\text { project carried out as part of the environmental } \\
\text { impact reassessment }\end{array}$ & $77-81$ \\
\hline \multirow{4}{*}{ 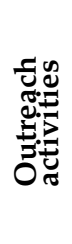 } & 1 & $\begin{array}{l}\text { Information posted on the internet } \\
\text { Websites dedicated to individual investments }\end{array}$ & $\begin{array}{l}1-120 \\
1-114\end{array}$ \\
\hline & 2 & Information meetings & $27-33,55-60$ \\
\hline & 3 & Press releases & $4-15,27-33$ \\
\hline & 4 & Flyers & $4-15,27-33$ \\
\hline
\end{tabular}

Source: Own elaboration based on data from General Directorate for National Roads and Motorways Olsztyn.

Construction of the S7 expressway between Miłomłyn and Olsztynek:

The Programme Concept prepared in 2006 presented two alternatives for the expressway route through Ostróda. One ran practically along the corridor of the then existing national road, the other, with better parameters (the one recommended), passed through undeveloped land, between two parts of a single-family housing estate. The recommended route, passing through an undeveloped part of the housing estate, allowed planners to maintain better geometrical parameters of the expressway, with much lower expenditures on the construction of bridges (shorter structures). During the public consultations carried out as part of the administrative proceedings for issue of the environmental decision, there were very considerable protests of the Waldowo residents aimed at blocking the route alternative that would pass through the settlement. The second alternative, designed within the framework of the Programme Concept, could not be implemented, as it collided with a nature monument and came very close to the neighbouring buildings (which did not fulfil the requirements of of providing a margin for future expansion of the road to the $2 \times 3$ cross-section). Intense social pressure contributed to looking to another alternative that would be socially acceptable, the so-called "social" alternative. A new alternative route was planned out, even more distant from the Waldowo settlement, at a cost of greater inter- 
ference with the shoreline of Pauzeńskie Lake. Despite the more expensive solutions of the "social" alternative, it was recommended for implementation, obtained the environmental decision, and finally was built.

Construction of the S7 Nidzica-Napierki expressway in 2007:

The Olsztyn Branch announced a tender for preparation of project documentation for the construction of the S7 expressway between Nidzica and Napierki. Following the comments gathered from the local community and the Mayor of Nidzica, it was decided to design and build two interchanges, Nidzica-North in the area of Litwinki village and Nidzica-South in the area of Tatary village, instead of one. This was done in order to enable a bypass to be constructed around Nidzica along DW 545 and DW 604. Moreover, such a solution provided better opportunities for development of the Nidzica commune thanks to the creation of well-communicated investment areas along the old route of DK7 between the Nidzica-North and the Nidzica-South interchanges.

The results of studies recently conducted in Poland have shown the evolution of the public participation phenomenon [66]. The survey conducted by Grzeszczak [38] among residents of 200 communes of different sizes (on a sample of 1000 respondents) focused primarily on detecting the level and the type of community involvement in decision-making processes. The results of the study for different communes show that only approximately $25 \%$ of their residents sought public information, $11 \%$ sought clarification, $10 \%$ took part in public consultations, and 10\% submitted opinions or suggestions. Only $2.5 \%$ of respondents took part in the work of teams composed of representatives of authorities and residents, and $1.9 \%$ in the work of teams composed only of residents. Considering the commune size criterion, the greatest willingness to participate in public consultations was declared by rural inhabitants and the lowest level of involvement in this procedure was declared by inhabitants of large cities.

This paper proposes to analyse public involvement in transport infrastructure projects based on the example of two strategic road construction projects in Poland:

(1) The Augustów bypass (first attempt, period of implementation of the project 19962007; second attempt, period of implementation of the project 2007-2014) and

(2) The southern bypass of Grodzisk Mazowiecki and Milanówek-the so-called new route for the road 719 (start of the project planning at the end of the 1970s, never implemented).

Regarding the first example, construction of the Augustów Bypass (a section of the strategic international Via Baltica route between Warsaw and Tallinn) was one of the most problematic infrastructure projects planned in Poland in the last decade. The route initially planned for the road would have interfered with the natural environment of the Rospuda Valley and was the object of a six-year long conflict between the environmentalists, who protested against the disruption of the natural environment of the area, and the inhabitants of Augustów, suffering from excessive road traffic noise and air pollution.

Since 1991, the Rospuda Valley has been a protected area. In spite of its strict protection status, in 1996 the decision was made to construct a bypass road in the vicinity of the Rospuda River and the unique, in the opinion of environmentalists, peatlands. In the same year, the first studies were drafted presenting several alternative routes. In 2002, public consultations were conducted, but they were only intended to meet the minimum requirements imposed by the law. At that time, information was obtained about the absence of environmental analyses and the objections on the part of environmental organisations. In spite of these findings, the decision was made to continue the work without modifications.

In 2004, the area of the Rospuda Valley was included in the Natura 2000 network. One year later, social dialogue was taken up again. Court and administrative proceedings continued until 2007. In the beginning of 2007, the construction work started despite an official protest of the European Commission. On 31 July 2007, the Prime Minister of the Republic of Poland put a stop to the investment project under the influence of the European Commission that had brought action against Poland to the European Court of 
Justice. As a result, the earlier project plan was changed completely. As a consequence, additional funds had to be spent on mitigating the negative effects of the previous operations and for modifying the project. The lack of response to the opinions of some groups of key stakeholders concerned with the location of the project route contributed to halting the ongoing construction work and to restarting the project planning activities and the administrative procedure.

In 2009, a decision was made to change the project route in order to bypass the area that was a source of conflict between the authorities, the residents of Augustów, and the organisations demanding protection of the environment. The project managers had learned a lesson from the first attempt at constructing the road. They took the power of public opinion into consideration. During the second attempt at the road construction some nonobligatory elements of public consultations were included, such as: conducting bilateral dialogues with the organisations, the community, and the local authorities; ensuring transparency of the activities conducted; organising meetings with residents; and making sure that information on subsequent project activities was provided before their start in publicly accessible media and on the website devoted to the project. Finally, 2014 saw the opening of the Augustów Bypass with a modified route passing through the village of Raczki, twice as long as the route originally planned through the Rospuda Valley, and not colliding with the Natura 2000 sites.

Regarding the second example, attempts to develop a road network in the western part of the Warsaw Metropolitan Area based on the new route for road 719 have been made since the end of 1970s. By 1990, the first detailed provisions were included in the Local General Land Development Plan for the town of Milanówek, adopted in 1978 and 1979. Already by then, a group of approximately a dozen citizens of Milanówek called for giving up the investment project due to the number of potential demolitions and possible disruption of the ecological balance. The provisions on the route for the road were reproduced, however, in each subsequent version of the planning documents. The ongoing protests of the inhabitants of Milanówek resulted in a proposal for a route running north of Grodzisk Mazowiecki and Milanówek (considered less controversial and traversing less developed agricultural areas and therefore entailing lesser implementation costs).

In 2003-2004, a polemical exchange of letters took place between the residents and the regional authorities that lasted for the next several years without bringing any tangible results. It appears that at that time the authorities of the region consistently pushed to implement the project, ignoring the demands of protesters and limiting the public debate to several information meetings [78]. In April 2007, the opponents of the bypass construction were joined by the Friendly Transport Association that immediately started a vigorous exchange of letters. Due to the increasing number of critical voices opposing the southern route scenario, the northern scenario, presented as an alternative, began to gain significance in the eyes of the local authorities. On 23 October 2008, a social agreement was made between the Mayor of Milanówek, the Milanówek Town Council, and the NGOs. Its signatories made a commitment to prepare new scenarios for the route of the 719 bypass road in accordance with the applicable EU regulations. At the beginning of 2009, certain initiatives, and in particular the interactive planning workshops initiated by Dr Halina Siemko-Tomaszewska in 2008, could have been a chance for a breakthrough in the dialogue conducted until then. At the same time, a tender procedure was announced to select the contractor for the preparation of the Economic, Technical and Environmental Study for the new route of the 719 road. The document was to facilitate the selection of the most advantageous route based on the analysis of several options. The workshops could have been a good occasion to help work out solutions that would have been acceptable to all parties concerned. Their potential success could have encouraged other local authorities to apply similar solutions. Unfortunately, the local authorities of all levels squandered this opportunity, deciding in favour of "consultations", fulfilling the minimum statutory requirements, announced as the only time and place for the parties concerned to give their opinion [39]. In 2010, the environmental assessment report was published. 
Finally, the southern bypass of Milanówek and Grodzisk Mazowiecki was never constructed. The Mayor of Grodzisk Mazowiecki refused to issue the environmental decision due to the deficiencies of the environmental assessment report that failed to comply with the guidelines of the Regional Directorate for Environmental Protection. Furthermore, in connection with strong public protests (including large-scale media protests), alternative solutions started to be considered, including the scenario of a northern bypass.

The analysis of the above-described objects of study was conducted with regard to three issues: (1) characteristics of the conflict (the presence of conflict, the object of conflict, the protesters, and the type of activities undertaken by the protesters), (2) public participation (the public participation techniques used, public participation ladder, and ad hoc or crisis management activities undertaken by the investor/authorities), and (3) formal evaluation of the implementation of the investment (duration of the investment and final outcome). The results of the study are presented in Table 4 below.

Table 4. Summary of the case studies.

\begin{tabular}{|c|c|c|c|}
\hline \multicolumn{4}{|c|}{ Object of Study } \\
\hline & \multicolumn{2}{|c|}{ Augustów Bypass } & \multirow{2}{*}{$\begin{array}{l}\text { Grodzisk Mazowiecki and } \\
\text { Milanówek Southern Bypass }\end{array}$} \\
\hline & 1st Attempt & 2nd Attempt & \\
\hline \multicolumn{4}{|c|}{ Conflict Characteristics } \\
\hline Presence of conflict & Yes & Yes & Yes \\
\hline Object of conflict & $\begin{array}{r}\text { The project route- }- \text { the section } \\
\text { Natura } 2000\end{array}$ & $\begin{array}{l}\text { the express road cutting through } \\
\text { rotected areas }\end{array}$ & $\begin{array}{l}\text { The investment project route } \\
\text { crossing through built-up areas, } \\
\text { decrease in landscape } \\
\text { attractiveness of the area, } \\
\text { in particular of the town of } \\
\text { Milanówek (the Garden Town) }\end{array}$ \\
\hline Protesters & $\begin{array}{r}\text { Environmer } \\
\text { local }\end{array}$ & $\begin{array}{l}1 \text { associations, } \\
\text { imunity }\end{array}$ & $\begin{array}{l}\text { Local community, "Friendly } \\
\text { Transport" Association }\end{array}$ \\
\hline $\begin{array}{l}\text { Activities undertaken } \\
\text { by the protesters }\end{array}$ & $\begin{array}{l}\text { Objections and protests of } \\
\text { environmental associations in } \\
\text { the media, as a result the } \\
\text { objection of the European } \\
\text { Commission }\end{array}$ & Submitting comments, opinions & $\begin{array}{l}\text { Objections and protests in the } \\
\text { media, submitting comments, } \\
\text { opinions }\end{array}$ \\
\hline \multicolumn{4}{|c|}{ Public Participation } \\
\hline $\begin{array}{l}\text { Public participation } \\
\text { techniques used }\end{array}$ & $\begin{array}{l}\text { Debate-open information } \\
\text { meeting }\end{array}$ & $\begin{array}{c}\text { Debate-open information } \\
\text { meeting } \\
\text { Quality interview }\end{array}$ & $\begin{array}{c}\text { Debate-open information } \\
\text { meeting } \\
\text { Interactive planning } \\
\text { workshops-attempt at } \\
\text { implementation blocked by the } \\
\text { local government authorities }\end{array}$ \\
\hline Public participation ladder & $\begin{array}{l}5 / 8 \\
\text { (right to be heard, without } \\
\text { influence on the } \\
\text { decision-making process) }\end{array}$ & $\begin{array}{c}7 / 8 \\
\text { (collaboration and co-decision) }\end{array}$ & $\begin{array}{l}5 / 8 \\
\text { (right to be heard, without } \\
\text { influence on the } \\
\text { decision-making process) }\end{array}$ \\
\hline $\begin{array}{l}\text { Activities undertaken by the } \\
\text { investor/authorities }\end{array}$ & $\begin{array}{l}\text { Informing about subsequent } \\
\text { stages of project } \\
\text { implementation, } \\
\text { information-consultation } \\
\text { meetings (consultation of the } \\
\text { project route alternatives) }\end{array}$ & $\begin{array}{l}\text { Informing about subsequent } \\
\text { stages of project } \\
\text { implementation, } \\
\text { information-consultation } \\
\text { meetings (consultation of the } \\
\text { project route alternatives), active } \\
\text { participation of stakeholders in } \\
\text { planning out the project route }\end{array}$ & $\begin{array}{l}\text { Informing about subsequent } \\
\text { stages of project } \\
\text { implementation, } \\
\text { information-consultation } \\
\text { meetings (consultation of the } \\
\text { project route alternatives) }\end{array}$ \\
\hline $\begin{array}{l}\text { Intervention from central } \\
\text { government }\end{array}$ & No & Yes & - \\
\hline \multicolumn{4}{|c|}{ Formal Evaluation of the Investment Implementation Process } \\
\hline $\begin{array}{l}\text { Duration of the process of } \\
\text { determining/agreeing on the } \\
\text { project route }\end{array}$ & 11 years & 4 years & Not implemented \\
\hline Decision & Not implemented & $\begin{array}{l}\text { Implemented as a result of a } \\
\text { consensus reached by the } \\
\text { parties concerned }\end{array}$ & Not implemented \\
\hline
\end{tabular}




\section{Discussion}

The concept of the model proposed by the authors, intended to consider the public's active participation in the decision-making process, is based on robust international models regarding "mature" tools of participation and can be described with the following flowchart (Figure 5).

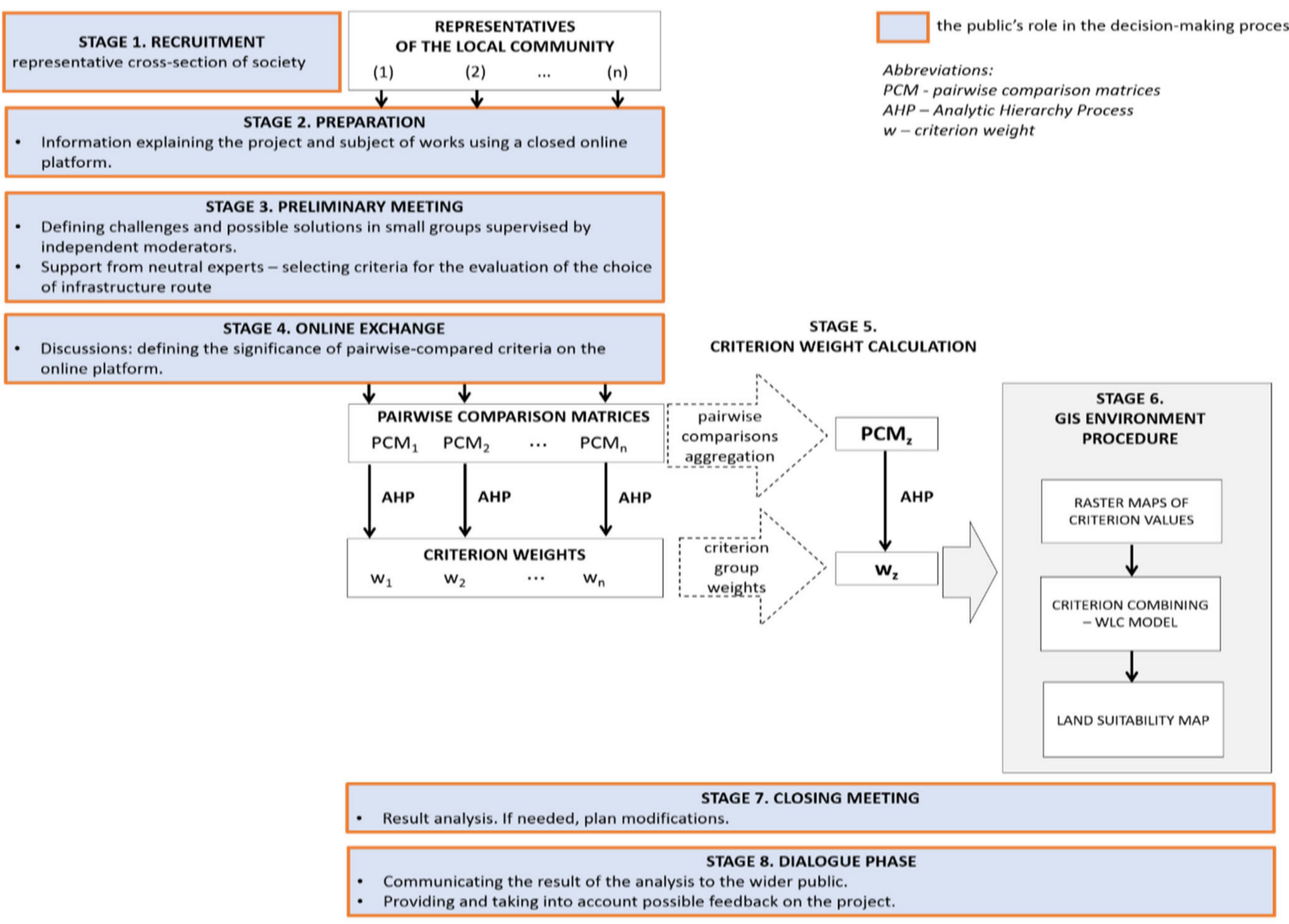

Figure 5. A model solution for including public participation in the process of designing road infrastructure. Source: Own elaboration.

At the beginning of the proposed procedure (stage 1), participants are recruited from among representatives of the local community with at least a secondary education degree, of different sexes and age groups, who are trusted by the local citizens.

At stage 2, the organisers, i.e., local government/investor representatives, proceed to describe the project and explain the goal, the nature of the decision problem, and successive work stages. They do this via a self-created online platform where articles, picture stories, photographs, graphics, and videos are shared. Subject-related questions are answered by experts (specialists in environmental protection, civil engineering, land surveying and mapping, economics, sociology, etc.).

Stage 3 involves organising a meeting where citizens work in small thematic groups (committees) led by independent moderators to define challenges and formulate their own ideas, reflections, initiatives, and possible solutions. A set of criteria is selected for the evaluation of the planned investment project, which is then subjected to expert evaluation (Table 3). Each criterion has to express a measurable degree to which a goal can be achieved. The AHP method is employed to model the decision problem into a hierarchical structure in order to gather all factors affecting the decision problem in one place.

Subsequently, at stage 4 and after determining the hierarchy of evaluation criteria, citizens participate in a discussion on the online platform to define criterion weights. To that 
end, the pairwise comparison method is employed to define the numerical relationship between two criteria bound by a common goal. Each value of a pairwise comparison constitutes a judgement that represents the dominance of one criterion over another. A judgement consists of answers to two questions: (1) which of the two criteria is more important (more significant) in relation to the goal and (2) how many times more important is it. This is represented on a numerical scale ranging from 1 (equal importance) to 9 (extreme importance). A set of all such judgements forms a square matrix where a set of criteria is compared to itself. Each participant of the decision-making process can develop their individual pairwise comparison matrices. Based on these matrices, a common (group) pairwise comparison matrix $\mathrm{PCMz}$ is created, the elements of which are defined as the geometric mean of individual paired comparisons.

After the entire matrix is filled out (stage 5), weight values are calculated using special computer software, e.g., Super Decisions, with real-time data consistency and conformity control. There are several methods, one of the most commonly used ones being the standard column average method.

Stage 6 of the procedure is executed in a GIS environment. Raster maps of criterion values are created, which are then combined using the weighted linear combination method, producing a recommendations map. Each cell of this map contains information on the value of the land's suitability for the main (fundamental) goal defined at the very top of the hierarchy, i.e., land suitable for the purpose of the road infrastructure project. The resulting suitability map can be used to create a ranking of suitability of alternatives, also known as the decision-maker preference profile, in this context decision makers being the local community.

According to stage 7 of the model, in the event of any spatial conflicts, the final result is analysed and, if needed, modified in partnership with the citizens.

The final, eighth stage of the procedure involves communicating the results to the wider public as well as collecting and considering possible feedback on the project.

\section{Conclusions}

In the proposed concept of the model, the residents take an active part in the project planning process by determining the significance of specific decision-making criteria and then analysing the obtained results together with other social groups. The above solution thus enables active participation of the public in the implemented transport infrastructure project corresponding to the highest rungs of the participation ladder, which are cooperation and co-decision. Through active and genuine participation in shaping their surroundings, the citizens assume shared responsibility for the actions taken and decisions made, which increases the sustainability and effectiveness of the entire process. The model's flexible structure allows it to be implemented globally in different types of transport infrastructure projects.

The proposed model is based on universal premises so as to allow its use in the broadly understood spatial planning process. The model is a modern form of communication between residents, the authorities, and the investors and enables active engagement of the residents in projects having an impact on their surroundings.

Research has shown that public participation has a positive effect on solutions developed for road investments. The study confirmed that the General Directorate for National Roads and Highways (GDDKiA) in Poland considers the results of public participation in mandatory documents during road construction projects. Additional documents have shown to be prepared by GDDKiA resulting from the opinions gathered from the public. A negative aspect of public participation in road construction projects is the prolonged implementation time from the initial idea to the actual construction. This is confirmed by the timeline of the Design Works Schedule, prepared by GDDKiA, presented in this paper for the S16 road construction project. To speed up project execution, it is necessary to implement and improve the proposed model. 
The authors, however, perceive a certain threat to the implementation of the model on a larger scale. The threat results from widespread acceptance among decision makers of limiting public participation in the investment planning process to the statutory minimum. The authors, however, express the hope that this proposal may be a chance, or at least an encouragement, for the decision makers to be open to new, more refined techniques of public participation. The authors see the need for more detailed studies into the possibilities of applying the model in transport infrastructure projects of various type in Poland and abroad.

Author Contributions: Conceptualization, M.O., W.K. and N.S.; methodology, M.O., W.K. and N.S.; software, M.O. and W.K.; validation, M.O. and W.K.; formal analysis, M.O., W.K. and N.S.; investigation, M.O., W.K. and N.S.; resources, M.O., W.K. and N.S.; data curation, M.O. and W.K.; writing-original draft preparation, M.O., W.K. and N.S.; writing-review and editing, M.O. and W.K.; visualization, M.O. and W.K.; supervision, M.O.; project administration, M.O; funding acquisition, M. O., W.K. and N.S. All authors have read and agreed to the published version of the manuscript.

Funding: This research received no external funding.

Data Availability Statement: Not applicable.

Conflicts of Interest: The authors declare no conflict of interest.

\section{References}

1. Bhatta, S.D.; Drennan, M.P. The economic benefits of public investment in transportation: A review of recent literature. J. Plan. Educ. Res. 2003, 22, 288-296. [CrossRef]

2. Preston, J.M.; Holvad, T. Road transport investment projects and additional economic benefits. In Proceedings of the 45th Congress of European Regional Science Association, Amsterdam, The Netherlands, 23-27 August 2005. Available online: http:/ / www-sre.wu.ac.at/ersa/ersaconfs/ersa05/papers/522.pdf (accessed on 4 October 2021).

3. Komornicki, T.; Rosik, P. Wpływ Budowy Autostrad i Dróg Ekspresowych na Rozwój Społeczno-Gospodarczy i Terytorialny Polski; Ministerstwo Rozwoju Regionalnego: Warsaw, Poland, 2013. Available online: https:/ /www.ewaluacja.gov.pl/media/24516/ Wp \T1 \lyw\%20budowy\%20autostrad\%20i\%20dróg\%20ekspresowych\%20na\%20rozwój\%20spo \T1 \leczno-gospodarczy\%20 i\%20terytorialny\%20Polski.pdf (accessed on 4 October 2021).

4. Borcz, Z. Infrastruktura Terenów Wiejskich; Wydawnictwo Akademii Rolniczej: Wrocław, Poland, 2000.

5. Ogryzek, M.; Adamska-Kmieć, D.; Klimach, A. Sustainable Transport: An Efficient Transportation Network-Case Study. Sustainability 2020, 12, 8274. [CrossRef]

6. Drumheller, B.; Quaid, A.; Wyman, M.; Liljenwall, J.; Young, A. Sustainable Transportation Options for Protecting the Climate; International Council for Local Environmental Initiatives: Berkeley, CA, USA, 2001.

7. Merkisz-Guranowska, A.; Merkisz, J.; Kozak, M.; Jacyna, M. Development of a sustainable road transport system. In Urban Transport XIX (WIT Transactions on the Built Environment); Wit Press: Billerica, MA, USA, 2013; pp. 507-517. [CrossRef]

8. Xu, X.; Chen, A.; Yang, C. A review of sustainable network design for road networks. KSCE J. Civ. Eng. 2016, $20,1084-1098$. [CrossRef]

9. Puodziukas, V.; Svarpliene, A.; Aivaras Braga, A. Measures for sustainable development of road network. Transp. Res. Procedia 2016, 14, 965-972. [CrossRef]

10. Lopez, E.; Monzon, A. Integration of sustainability issues in strategic transportation planning: A multi-criteria model for the assessment of transport infrastructure plans. Comput. Aided Civ. Infrastruct. Eng. 2010, 25, 440-451. [CrossRef]

11. Ford, A.C.; Barr, S.L.; Dawson, R.J.; James, F. Transport accessibility analysis using GIS: Assessing sustainable transport in London. ISPRS Int. J. Geo. Inf. 2015, 4, 124-149. [CrossRef]

12. Sajnóg, N.; Sobolewska-Mikulska, K.; Wójcik-Leń, J. Methodology of determination of the range of restrictions related to the existence of transmission devices on private land-Case study of Poland. Sustainability 2019, 11, 3786. [CrossRef]

13. Truffer, B.; Störmer, E.; Maurer, M.; Ruef, A. Local strategic planning processes and sustainability transitions in infrastructure sectors. Environ. Policy Gov. 2010, 20, 258-269. [CrossRef]

14. Banister, D. Assessing the Reality-Transport and Land Use Planning to Achieve Sustainability. J. Transp. Land Use 2012, 5, 1-14. [CrossRef]

15. Malekpour, S.; Brown, R.R.; de Haan, F.J. Strategic planning of urban infrastructure for environmental sustainability: Understanding the past to intervene for the future. Cities 2015, 46, 67-75. [CrossRef]

16. Gibberd, J. Strengthening sustainability planning: The city capability framework. Procedia Eng. 2017, 198, 200-211. [CrossRef]

17. Smyth, A.J.; Dumanski, J. FESLM: An International Framework for Evaluating Sustainable Land Management; World Soil Resources Report; Food and Agriculture Organization of the United Nations: Rome, Italy, 1993. Available online: http://www.faoswalim. $\mathrm{org} /$ resources/Land/Land_resource_Mgt/pdfdocs/feslm.pdf (accessed on 4 October 2021). 
18. Williamson, J.F.; Enemark, S.; Wallace, J.; Rajabifard, A. Land administration for sustainable development. In Proceedings of the FIG Congress 2010 Facing the Challenges-Building the Capacity, Sydney, Australia, 11-16 April 2010.

19. Ng, C.P.; Law, T.H.; Jakarni, F.M.; Kulanthayan, S. Relative improvements in road mobility as compared to improvements in road accessibility and urban growth: A panel data analysis. Transp. Res. Part A Policy Pract. 2018, 117, 292-301. [CrossRef]

20. Ogryzek, M.; Wolny-Kucińska, A. Sustainable Development of Transport as a Regional Policy Target for Sustainable Development-A Case Study of Poland. ISPRS Int. J.Geo. Inf. 2021, 10, 132. [CrossRef]

21. Radziszewski, P.; Nazarko, J.; Vilutiene, T.; Dębkowska, K.; Ejdys, J.; Gudanowska, A.; Halicka, K.; Kilon, J.; Kononiuk, A.; Kowalski, K.J.; et al. Future trends in road pavement technologies development in the context of environmental protection. Balt. J. Road Bridge Eng. 2016, 11, 160-168. [CrossRef]

22. Chang, T.S.; Tseng, J.-S.; Hsieh, T.-H.; Hsu, Y.-T.; Lu, Y.-C. Green transportation implementation through distance-based road pricing. Transp. Res. Part A Policy Pract. 2018, 111, 53-64. [CrossRef]

23. Dear, M. Understanding and overcoming the NIMBY syndrome. J. Am. Plan. Assoc. 1992, 58, 288-300. [CrossRef]

24. Hermansson, H. The ethics of NIMBY conflicts. Ethical Theory Moral Pract. 2007, 10, 23-34. [CrossRef]

25. Van der Horst, D. NIMBY or not? Exploring the relevance of location and the politics of voiced opinions in renewable energy siting controversies. Energy Policy 2007, 35, 2705-2714. [CrossRef]

26. Wolsink, M. Wind power and the NIMBY-myth: Institutional capacity and the limited significance of public support. Renew. Energy 2000, 21, 49-64. [CrossRef]

27. Bell, D.; Gray, T.; Haggett, C.; Swaffield, J. Re-visiting the 'social gap': Public opinion and relations of power in the local politics of wind energy. Environ. Politics 2013, 22, 115-135. [CrossRef]

28. Gallagher, L.; Ferreira, S.; Convery, F. Host community attitudes towards solid waste landfill infrastructure: Comprehension before compensation. J. Environ. Plan. Manag. 2008, 51, 233-257. [CrossRef]

29. Wolsink, M.; Denville, J. The motives for accepting or rejecting waste infrastructure facilities. Shifting the focus from the planners' perspective to fairness and community commitment. J. Environ. Plan. Manag. 2009, 52, 217-236. [CrossRef]

30. Upreti, B.R. Conflict over biomass energy development in the United Kingdom: Some observations and lessons from England and Wales. Energy Policy 2004, 32, 785-800. [CrossRef]

31. Mann, S.; Koegl, H. On the acceptance of animal production in rural communities. Land Use Policy 2003, 20, 243-252. [CrossRef]

32. Linlin, S.; Esther, H.K.Y.; Edwin, H.W.C.; Dajian, Z. Issues of NIMBY conflict management from the perspective of stakeholders: A case study in Shanghai. Habitat Int. 2016, 53, 133-141. [CrossRef]

33. Ogryzek, M.; Klimach, M.; Niekurzak, D.; Pietkiewicz, M. Using Cartographic Documents to Provide Geoinformation on the Rights to Real Estate-Taking Poland as an Example. ISPRS Int. J. Geo. Inf. 2019, 8, 530. [CrossRef]

34. Krupowicz, W.; Sobolewska-Mikulska, K.; Burinskienè, M. Modern trends in road network development in rural areas. Balt. J. Road Bridge Eng. 2017, 12, 48-56. [CrossRef]

35. Dmochowska-Dudek, K.; Bednarek-Szczepańska, M. A profile of the Polish rural NIMBYist. J. Rural. Stud. 2018, 58, 52-66. [CrossRef]

36. Patel, M.; Kok, K.; Rothman, D. Participatory scenario construction in land use analysis: An insight into the experiences created by stakeholder involvement in the northern Mediterranean. Land Use Policy 2007, 24, 546-561. [CrossRef]

37. Szopinska, K. Sustainable Urban Transport and the Level of Road Noise-A Case Study of the City of Bydgoszcz. Geomat. Environ. Eng. 2019, 13, 93-107. [CrossRef]

38. Leśniewski, M.; Świąder, M.; Kaczmarek, I.; Castro, D.G.; Kamińska, J.A.; Pilawka, T.; Kazak, J.K. Towards Transit Oriented Development for Sustainable Urban Mobility: Insights from a Central European City. Geomat. Environ. Eng. 2021, 15, 39-53. [CrossRef]

39. Telega, A.; Telega, I.; Bieda, A. Measuring Walkability with GIS-Methods Overview and New Approach Proposal. Sustainability 2021, 13, 1883. [CrossRef]

40. Yin, R.K. Case Study Research: Design and Method, 4th ed.; Sage Publication: Thousand Oaks, CA, USA, 2009.

41. Nam, T.; Pardo, T.A. Conceptualizing smart city with dimensions of technology, people, and institutions. In Proceedings of the 12th Annual Digital Government Research Conference, College Park, MD, USA, 12 June 2011; pp. 282-291. Available online: https: / /dl.acm.org/doi/abs/10.1145/2037556.2037602 (accessed on 5 February 2020).

42. Ogryzek, M.; Tarantino, E.; Rzasa, K. Infrastructure of the Spatial Information in the European Community (INSPIRE) Based on Examples of Italy and Poland. ISPRS Int. J. Geo Inf. 2020, 9, 755. [CrossRef]

43. Myeong, S.; Kim, Y.; Ahn, M.J. Smart City Strategies-Technology Push or Culture Pull? A Case Study Exploration of Gimpo and Namyangju, South Korea. Smart Cities 2021, 4, 41-53. [CrossRef]

44. Act of June 1960-The Code of Administrative Procedure, Consolidated text, Dz. U. (Journal of Laws) of 2021 Item 735 with changes. Available online: http:/ /isap.sejm.gov.pl/isap.nsf/download.xsp/WDU19600300168/U/D19600168Lj.pdf (accessed on 20 October 2021).

45. Grzeszczak, J. Partycypacja publiczna w dużych miastach. In Dyktat czy Uczestnictwo? Diagnoza Partycypacji Publicznej w Polsce; Olech, A., Ed.; Instytut Spraw Publicznych: Warsaw, Poland, 2012; Volume 1.

46. Hackiewicz, M. Społeczne i prawne aspekty konfliktów na tle zagospodarowania przestrzennego na przykładzie budowy obwodnicy Milanówka i Grodziska Mazowieckiego. MAZOWSZE Studia Reg. 2011, 6, 123-148. Available online: http://cejsh. icm.edu.pl/cejsh/element/bwmeta1.element.desklight-e2adfae8-4ffe-4a67-b091-4acc7a0c744b (accessed on 4 October 2021). 
47. Chrzanowski, O. Partycypacja Publiczna Krok po Kroku; FISE-Fundacja Inicjatyw Społeczno-Ekonomicznych: Warsaw, Poland, 2014. Available online: http:/ / dobrepraktyki.decydujmyrazem.pl/files/fise_partycypacja_w_praktyce_www.pdf (accessed on 4 October 2021).

48. Poorazizi, M.E.; Steiniger, S.; Hunter, A.J.S. A service-oriented architecture to enable participatory planning: An E-planning Platform. Int. J. Geogr. Inf. Sci. 2015, 29, 1081-1110. [CrossRef]

49. Saaty, T.L. How to make a decision: The analytic hierarchy process. Eur. J. Oper. Res. 1994, 48, 9-26. [CrossRef]

50. ProCon.org. Benjamin Franklin's 1772 Letter to Joseph Priestley. Available online: http://www.procon.org/view.back-groundresource.php?resourceID=1474 (accessed on 16 November 2021).

51. Carr, M.H.; Zwick, P.D. Smart Land-Use Analysis: The LU-CIS Model Land Use Identification Strategy; ESRI Press: Redlands, CA, USA, 2007; p. 277.

52. Geneletti, D. Multicriteria Analysis to Compare the Impact of Alternative Road Corridors: A Case Study in Northern Italy. Impact Assess. Proj. Apprais. 2005, 23, 135-146. [CrossRef]

53. Saaty, T.L. Fundamentals of decision making and priority theory with the analytic hierarchy process. In AHP Series; RWS Publications: Pittsburgh, PA, USA, 2000; Volume 6.

54. Saaty, T.L. Decision making with the analytic hierarchy process. Int. J. Serv. Sci. 2008, 1, 83-98. [CrossRef]

55. Malczewski, J. GIS-based multicriteria decision analysis: A survey of the literature. Int. J. Geo. Inf. Sci. 2006, $20,703-726$. [CrossRef]

56. Kalamaras, G.S.; Brino, L.; Carrieri, G.; Pline, C.; Grasso, P. Application of multicriteria analysis to select the best highway alignment. Tunn. Undergr. Space Technol. 2000, 15, 415-420. [CrossRef]

57. Malczewski, J. Multiple criteria decision analysis and geographic information systems. In Trends in Multiple Criteria Decision Analysis: International Series in Operations Research \& Management Science; Ehrgott, M., Figueira, J., Greco, S., Eds.; Springer: Boston, MA, USA, 2010; Volume 142, pp. 369-395.

58. Bielska, A.; Jaroszewicz, J. Przegląd metod wykorzystujących funkcje rozmyte i analizy wielokryterialne do opracowania cyfrowych map glebowo-rolniczych. Acta Sci. Pol. Geod. Descr. Terrarum 2012, 11, 5-15.

59. Cay, T.; Uyan, M. Evaluation of reallocation criteria in land consolidation studies using the Analytic Hierarchy Process (AHP). Land Use Policy 2013, 30, 541-548. [CrossRef]

60. Malczewski, J.; Rinner, C. Multicriteria Decision Analysis in Geographic Information Science; Springer: New York, NY, USA, 2015.

61. Jaroszewicz, J.; Rędzińska, K. Funkcja agregująca w przestrzennej analizie wielokryterialnej procesów przyrodniczych. Roczniki Geomatyki 2019, 17, 41-57.

62. Telega, A.; Bieda, A. Analizy stopnia dopasowania sposobu użytkowania ziemi jako narzędzie zarządzania konfliktami przestrzennymi. Infrastrukt. Ekol. Teren. Wiej. 2015, 4, 1007-1020. [CrossRef]

63. Carver, S.J. Integrating multi-criteria evaluation with geographical information systems. Int. J. Geogr. Inf. Syst. 1991, 5, 321-339. [CrossRef]

64. Pereira, J.M.C.; Duckstein, L. A multiple criteria decision-making approach to GIS based land suitability evaluation. Int. J. Geogr. Inf. Syst. 1993, 7, 407-424. [CrossRef]

65. Eastman, J.R. Multi-criteria evaluation and GIS. In Geographical Information Systems; Goodchild, M.F., Maguire, D.J., Rhind, D.W., Eds.; John Wiley and Sons: New York, NY, USA, 1999; pp. 493-502.

66. Urbanik, A.; Boni, Z.; Koczanowicz-Chondzyńska, J. Udział Obywateli w Tworzeniu Polityk Publicznych. Wybór Dobrych Praktyk Zagranicznych; Fundacja Inicjatyw Społeczno-Ekonomicznych: Warsaw, Poland, 2010. Available online: https: // partycypacjaobywatelska.pl/wp-content/uploads/2015/06/udzia\%C5\%82-obywateli.pdf (accessed on 4 October 2021).

67. Chmiel, J. Analizy przestrzenne i modelowanie. In Informacja Przestrzenna dla Samorzadów Terytorialnych; Białousz, S., Ed.; Oficyna Wydawnicza Politechniki Warszawskiej: Warsaw, Poland, 2013; pp. 217-266.

68. Hindsworth, M.F.; Lang, T.B. Community Participation and Empowerment; Nova Science Publishers: New York, NY, USA, 2009.

69. Bednarek-Szczepańska, M.; Dmochowska-Dudek, K. Syndrom NIMBY jako wyzwanie dla jednostek samorządu terytorialnego. MAZOWSZE Studia Reg. 2017, 21, 103-114. [CrossRef]

70. Creighton, J.L. The Public Participation Handbook; Jossey-Bass: San Francisco, CA, USA, 2005.

71. Arnstein, S.R. A ladder of citizen participation. J. Am. Inst. Plan. 1969, 35, 216-224. [CrossRef]

72. European Institute for Public Participation (EIPP). Public Participation in Europe: An International Perspective. 2009. Available online: https:/ / cupdf.com/document/public-participation-in-public-participation-in-europe-eipp-june-2009-page-6-the.html (accessed on 4 October 2021).

73. European Center for Not-for-Profit Law (ECNL). Civil Participation in Decision-Making Processes: An Overview of Standards and Practices in Council of Europe Member States; European Committee on Democracy and Governance: Strasbourg, France, 2016; Available online: https:/ / rm.coe.int/civil-participation-in-decision-making-processes-an-overview-of-standa/1680701801 (accessed on 22 November 2021).

74. Dobosz-Mucha, A.; Goras, E.; Jadach-Sepioło, A.; Janas, K.; Kudłacz, K.; Matuszko, A.; Mikołajczyk, D.; Nowak, K.; Ogrodowski, J.; Spadło, K.; et al. Przestrzeń do Dialogu. Praktyczny Podręcznik o Tym, Jak Prowadzić Partycypacje Społeczna w Planowaniu Przestrzennym; Ministerstwo Inwestycji i Rozwoju: Warsaw, Poland, 2018.

75. Pijanowski, J.M.; Zedler, J. Koncepcja Postępowania dla Zintegrowanego Rozwoju Obszarów Wiejskich Włacznie z Propozycjami dla Prowadzenia Przyszłych Postępowań; Urząd Marszałkowski Województwa Małopolskiego: Kraków, Poland, 2015. 
76. Pułecka, A. Propozycja modyfikacji procesu scalania gruntów jako narzędzia kształtowania krajobrazu. In Wspótczesne Problemy Katastru i Gospodarki Nieruchomościami; Wilkowski, W., Budzyński, T., Sobolewska-Mikulska, K., Pułecka, A., Eds.; Oficyna Wydawnicza Politechniki Warszawskiej: Warsaw, Poland, 2006.

77. Hansen, H.S.; Prosperi, D.C. Citizen Participation and Internet GIS-Some Recent Advances. Ed. Comput. Environ. Urban Syst. 2005, 29, 617-629. [CrossRef]

78. Andrzejewska, M.; Baranowski, M.; Fiedziukiewicz, K.; Kowalska, A.; Matuszkiewicz, J.M.; Rusztecka, M.; Roo-Zielińska, E.; Solo, J. O Partycypacji Społecznej w Planowaniu Przestrzennym; Centrum Informacji o Środowisku UNEP/GRID i Instytut Geografii i Przestrzennego Zagospodarowania PAN: Warsaw, Poland, 2007. Available online: http:/ / www.decydujmyrazem.pl/files/O_ partycypacji_spolecznej_w_planowaniu_przestrzennym.pdf (accessed on 22 November 2021).

79. Hanzl, M. Information technology as a tool for public participation in urban planning: A review of experiments and potentials. Des. Stud. 2007, 28, 289-307. [CrossRef]

80. Hanzl, M. Technologie informacyjne jako narzędzie udziału społecznego w kształtowaniu przestrzeni. Rocz. Geomatyki 2008, 6, 87-99. Available online: http://rg.ptip.org.pl/index.php/rg/article/view / RG2008-3-Hanzl/1153 (accessed on 22 November 2021).

81. INSPIRE. Directive 2007/2/EC of the European Parliament and of the Council of 14 March 2007 Establishing an Infrastructure for Spatial Information in the European Community (OJ L 108, 25 April 2007, 1-14).

82. Sajnóg, N. Social Communication Programmes in the Investment Process Concerning Infrastructure Investments in Poland. Geodesy and Mine Surveing. Int. Multidiscip. Sci. Geo Conf. 2018, 18, 955-962. [CrossRef]

83. The Constitution of the Republic of Poland Dated 2 April 1997; Sejm Rzeczypospolitej Polskiej: Warsaw, Poland, 1997.

84. The Act of October 2008 on Providing Information on the Environment and Environmental Protection, Public Participation in Environmental Protection and on Environmental Impact Assessment, Consolidated Text, Dz. U. (Journal of Laws) of 2021 Item 247 with changes. Available online: https:/ / isap.sejm.gov.pl/isap.nsf/download.xsp/WDU20081991227/U/D20081227Lj.pdf (accessed on 4 October 2021).

85. The Act of 27 March 2003 on Spatial Planning and Management, Consolidated Text, Dz. U. (Journal of Laws) of 2021 Item 741 with changes. Available online: http:/ /isap.sejm.gov.pl/isap.nsf/download.xsp/WDU20030800717/U /D20030717Lj.pdf (accessed on 4 October 2021).

86. Główny Urząd Statystyczny. Bank Danych Lokalnych. 2019. Available online: https://bdl.stat.gov.pl/BDL/start (accessed on 22 November 2021).

87. Matczak, P. Społeczne uwarunkowania eliminacji syndromu NIMBY. In Podmiotowość Społeczności Lokalnych. Praktyczne Programy Wspomagania Rozwoju; Cichocki, R., Ed.; Wydawnictwo Media G-T: Poznań, Poland, 1996.

88. Haggett, C. Understanding public responses to offshore wind power. Energy Policy 2011, 39, 503-510. [CrossRef]

89. Haggett, C. Over the sea and far away? A consideration of the planning, politics and public perception of offshore wind farms. J. Environ. Policy Plan. 2008, 10, 289-306. [CrossRef]

90. Schively, C. Understanding the NIMBY and LULU phenomena: Reassessing our knowledge base and informing future research. J. Plan. Lit. 2007, 21, 255-266. [CrossRef]

91. Nowak, M. Protesty lokalizacyjne jako egzemplifikacja zmiany systemowej połowy lat dziewięćdziesiątych. In Konflikt Nieunikniony. Wspólnoty i Władze Lokalne Wobec Konfliktów Spowodowanych Rozwojem; Buczkowski, P., Matczak, P., Eds.; Wydawnictwo Wyższej Szkoły Bankowej w Poznaniu: Poznań, Poland, 2004; pp. 67-79.

92. Matczak, P. Lokalne protesty na tle ochrony środowiska. In Konflikt Nieunikniony. Wspólnoty i Władze Lokalne Wobec Konfliktów Spowodowanych Rozwojem; Buczkowski, P., Matczak, P., Eds.; Wydawnictwo Wyższej Szkoły Bankowej w Poznaniu: Poznań, Poland, 2004; pp. 59-65.

93. Śliwińska, M. Rola, przyczyny i skutki dominacji interesów indywidualnych nad ogólnospołecznymi w konfliktach środowiskowych. In Konflikt Nieunikniony: Wspólnoty i Władze Lokalne Wobec Konfliktów Spowodowanych Rozwojem; Buczkowski, P., Matczak, P., Eds.; Wydawnictwo Wyższej Szkoły Bankowej w Poznaniu: Poznań, Poland, 2004; pp. 81-88.

94. Krajewska, H. Konflikt w gospodarce przestrzennej. In Przestrzeń $w$ Zarzadzaniu Rozwojem Regionalnym $i$ Lokalnym; Markowski, T., Ed.; Komitet Przestrzennego Zagospodarowania Kraju PAN: Warsaw, Poland, 2004; Volume 211, pp. 337-354.

95. Bednarek-Szczepańska, M.; Dmochowska-Dudek, K. Syndrom NIMBY na Obszarach Wiejskich w Polsce. Specyfika i Uwarunkowania Konfliktów Wokót Lokalizacji Niechcianych Inwestycji; IGIPZ PAN: Warsaw, Poland, 2016.

96. Janus, J.; Markuszewska, I. Land consolidation — a great need to improve effectiveness. A case study from Poland. Land Use Policy 2017, 65, 143-153. [CrossRef]

97. Kupidura, A.; Łuczewski, M.; Home, R.; Kupidura, P. Public perceptions of rural landscapes in land consolidation procedures in Poland. Land Use Policy 2014, 39, 313-319. [CrossRef]

98. Brzeziński, C. Wybrane problemy planowania przestrzennego w Polsce. Acta Univ. Lodz. Folia Oecon. 2013, 289, 105-114 Available online: http:/ / cejsh.icm.edu.pl/cejsh/element/bwmeta1.element.hdl_11089_10427/c/07-brzezinski.pdf (accessed on 22 November 2021).

99. Sajnóg, N. Infrastruktura techniczna związana z przesyłem i dystrybucją mediów oraz towarzyszące jej pasy terenu. In Infrastruktura i Ekologia Terenów Wiejskich; Polska Akademia Nauk: Warsaw, Poland, 2014; pp. 467-480. Available online: http:/ / dx.medra.org/10.14597/infraeco.2014.2.2.034 (accessed on 22 November 2021). 
100. Giuliani, M.V.; Feldman, R. Place attachment in a developmental and cultural context. J. Environ. Psychol. 1993, 13, $267-274$. [CrossRef]

101. Lewicka, M. Place attachment: How far have we come in the last 40 years? J. Environ. Psychol. 2011, 31, 207-230. [CrossRef]

102. Devine-Wright, P. Think global, act local? The relevance of place attachments and place identities in a climate changed world. Glob. Environ. Chang. 2013, 23, 61-69. [CrossRef]

103. Mandal, A.; Latusek, A. Przywiązanie do miejsca zamieszkania w biegu życia. Psychol. Rozw. 2015, 20, 73-87. [CrossRef]

104. Jorgensen, B.S.; Stedman, R.C. Sense of place as an attitude: Lakeshore owners' attitudes towards their properties. J. Environ. Psychol. 2001, 21, 233-248. [CrossRef]

105. Moore-Colyer, R.; Scott, A. What kind of landscape do we want? Past, present and future perspectives. Landsc. Res. 2005, 30, 501-523. [CrossRef]

106. Bastian, C.T.; Keske, C.M.H.; McLeod, D.M.; Hoag, D.L. Landowner and land trust agent preferences for conservation easement: Implications for sustainable land uses and landscape. Landsc. Urban Plan. 2017, 157, 1-13. [CrossRef]

107. Anton, C.E.; Lawrence, C. The relationship between place attachment: The theory of planned behaviour and residents' response to place change. J. Environ. Psychol. 2016, 47, 145-154. [CrossRef]

108. Brown, G.; Raymond, C. The relationship between place attachment and landscape values: Toward mapping place attachment. Appl. Geogr. 2007, 27, 89-111. [CrossRef] 